Marquette University

e-Publications@Marquette

4-1-2000

Unions, Cartels, and the Political Economy of American Cities: the Chicago Flat Janitors' Union in the Progressive Era and 1920s

John Jentz

Marquette University

Published version. Studies in American Political Development, Vol. 14, No. 1 (April 2000): 51-71.

DOI. (C) Cambridge University Press 2000. Used with permission. 


\section{Unions, Cartels, and the Political Economy of American Cities: the Chicago Flat Janitors' Union in the Progressive Era and 1920s}

\section{John B. Jentz, Marquette University}

In 1997, Ira Katznelson contributed to the ongoing discussion among social scientists and historians about how to analyze class formation and the development of the American state. He was particularly interested in tying this research to the history of liberalism in an effort to both historicize the generalizations of Louis Hartz and address the question of American exceptionalism. Evaluating the body of research, Katznelson argued that authors had too frequently abstracted the state from its context and then used it to explain the very phenomena that helped define the state's character in the first place. In part to imbed the state more concretely in its environment, he suggested "a shift in angle of vision away from the state as such to the character of the rules and institutions that govern the transactions between the state and civil society." This shift would also contribute to the study of America's prevailing liberalism, which has shaped the environment of the working class and the state, even while its own particular character has been the subject of some of the most profound divisions in American public life. Using

The researching and writing of this essay was supported in part by the Service Employees International Union. The conclusions expressed by the author do not necessarily represent the views of the SEIU.

In 1921 the Chicago Flat Janitors' Union became Local 1 of the new Building Service Employees' International Union, the predecessor of the SEIU. To help commemorate its 75th anniversary in 1996, the SEIU sponsored an historical project, which was based at the Family and Community History Center of the Newberry Library. This is the third and final article to result from the project. Earlier versions of this essay profited from critical readings by James R. Grossman, Bruce C. Nelson, Steven Rosswurm, and Richard Schneirov. The author would like to thank these critics as well as the anonymous reviewers for this journal for their insights.
J. David Greenstone's work, Katznelson defined liberalism as a "boundary condition," that is, "a set of relatively permanent features of a particular context that affect causal relationships within it' even as it remains subject to dispute." In times of crisis, conflicts over liberalism's "grammar of rules," or it's "bundle of institutions and norms," spill across the line between state and civil society, because they involve redefining the relation between the two. ${ }^{1}$

The seemingly parochial history of the Chicago Flat Janitors' Union impinges on these conceptual issues, but analyzing exactly how requires the "middlerange" theory that Katznelson and other social scientists have long called for. Between 1912 and 1917 the Chicago Flat Janitors' Union organized the great majority of the city's janitors servicing buildings with apartments, or "flats," into one huge interracial local with over 6,000 members, most of them immigrants. ${ }^{2}$ In 1917, the union won a city-wide contract and a closed shop in negotiations with Chicago's largest organizations of real estate agents and owners, led by the Chicago Board of Real Estate. Subsequently, contracts were negotiated annually amidst much acrimony and sometimes violence. By 1920, the city's most powerful political faction, the Republicans under Mayor "Big Bill" Thompson, became regularly involved in resolving the annual disputes through a va-

1. Ira Katznelson, "Working-Class Formation and American Exceptionalism, Yet Again," in American Exceptionalism? US WorkingClass Formation in an International Context, ed. Rick Halpern and Jonathan Morris (New York: St. Martin's Press, 1997), 36-55, quotations on 40 and 42 .

2. The union's over 6,000 members were two-thirds immigrant and one-fifth African American, with the remainder comprised overwhelmingly of children of immigrants. 
riety of arbitrators. By April 1921, the Flat Janitors were strong enough to form the organizational core of a new international union affiliated with the American Federation of Labor (AFL) - the Building Service Employees' International Union. ${ }^{3}$

Within a month, the Flat Janitors' ten top leaders were indicted in Chicago's Circuit Court on a host of charges ranging from various acts of violence to conspiracy. Although initially acquitted in February 1922, the Flat Janitors' leaders were convicted of conspiracy in a second trial five months later. After an extended court battle and a massive state-wide petition campaign, the governor of Illinois, who was closely affiliated with Thompson's faction, pardoned all ten leaders in early 1924. ${ }^{4}$

Recovering its balance, the Flat Janitors' Union expanded its labor organizing and enhanced its significant role as a player in Chicago politics. During the years of legal battles, the union maintained its closed shop and annual labor contracts, preserving the substantial gains achieved during World War I amidst an aggressive national open shop campaign by employers. The union was able to achieve these successes, despite the legal attacks upon it, in part because the Chicago Board of Real Estate wanted contract negotiations with the Flat Janitors to continue. The Board also did not support the legal assault on the union to the extent one would expect, given its public pronouncements. Other business groups pressed the legal case.

The middle-range interpretive concepts needed to analyze the Flat Janitors' history have to illucidate the interrelationships between labor, capital, and political parties in a local urban setting. The various works on politics by labor historians illuminate some of these relationships, but provide too little guidance on how capital fits together with both labor and political parties. The concept of corporatism used to analyze European industrial democracies ties the three elements together; but corporatism does not, in fact, apply well enough to American conditions. Nonetheless, the scholarship on corporatism provides valuable insights into the formation and interrelation of interests. Most appropriate to the case of the Flat Jan-

3. Katznelson calles for middle-range theory in ibid., 39; Theda Skocpol refers to it in "Bringing the State Back In: Strategies of Analysis in Current Research," in Bringing the State Back In, ed. Peter B. Evans, Dietrich Rueschemeyer, and Theda Skocpol (Cambridge: Cambridge University Press, 1985), 28; both are referring the work of Robert Merton. On the history of the Flat Janitors, see John B. Jentz, "Labor, the Law, and Economics: The Organization of the Chicago Flat Janitors' Union, 1902-1917," Labor History 38 (1997): 413-31; Jentz, "Citizenship, Self-Respect, and Political Power: Chicago's Flat Janitors Trailblaze the Service Employees International Union, 1912-1921," Labor's Heritage 9 (1997): 4-23; Tom Beadling, Pat Cooper, and Grace Palladino, A Need For Valor: The Roots of the Service Employees International Union, 1902-1992 (Washington, DC: Service Employees International Union, 1992), $1-15$.

4. The history of the Flat Janitors' Union in the 1920s is presented subsequently in this article. itors' Union is the concept of a political cartel that combines the notion of regulatory unionism in metropolitan economies with that of political factions and machines.

Since most scholarship on labor and politics in the Progressive Era concentrates on the policies of the AFL, it focuses mainly on politics at the state and national levels. This is also the case with recent studies that have considerably expanded the scholarly view of AFL politics beyond the former narrow conceptions of nonpartisan, even antipolitical, volunarism. In contrast, community-based labor histories since the 1960s have addressed the role of labor on the local level more directly, painting a rich picture of labor politics in industrialized cities and towns. This work concentrates on moments of upheaval when classbased political movements took over local governments, although these moments ended when the major parties returned to power, commonly by coopting leaders and issues from the labor movement. Typically, this scholarship sees the major parties, as well as the American democratic state at large, as diversionary of labor's distinctive interests and amielorative of class conflict. An analogous view of the major parties and the state emerges in the work of political scientists interested in class formation, although they draw different implications. Amy Bridges sees allegiance to a major party as the central Americanizing experience of immigrant workers before the Civil War. Martin Shefter sees craft unions and political machines defining the distinctive accommodation of the American working class to the industrial system, in which its class interests at the workplace were separated from working-class politics based in local communities. Both Bridges and Shefter assume that unions and political parties pulled workers in different directions, a tension that was not experienced by members of the Flat Janitors' Union, who were both politicized and Americanized by an AFL union of unskilled workers. ${ }^{5}$

5. Monographic reevaluations of the AFL on the national level include Victoria C. Hattam, Labor Visions and State Power: The Origins of Business Unionism in the United States (Princeton, NJ: Princeton University Press, 1993); Joseph A. McCartin, Labor's Great War: The Struggle for Industrial Democracy and thge Origins of Modern American Labor Relations, 1912-1921 (Chapel Hill: University of North Carolina Press 1997); and Julie Greene, Pure and Simple Politics: The American Federation of Labor and Political Activism, 1881-1917 (Cambridge: Cambridge University Press, 1998). For overviews of the voluminous scholarship on labor history published since the 1960 s as it pertains to politics see Greene, "Introduction," in ibid., 4-12; Richard Oestreicher, "Urban WorkingClass Political Behavior and Theories of American Electoral Politics, 1870-1940," Journal of American History 74 (1988): 125786; David Brody, "Labor Movement," in Encyclopedia of American Political History: Studies of the Principal Movements and Ideas, ed. Jack P. Greene, 3 vols. (New York: Charles Scribner's Sons), 2:709-27. For political scientists interested in class formation and the state see Amy Bridges, "Becoming American: The Working Classes in the United States before the Civil War," and Martin Shefter, "Trade Unions and Political Machines: The Organization and Dissorganization of the American Working Class in the Late Nineteenth Cen- 
Most important, practically all this scholarship by labor historians and political scientists uses the major parties and the state as independent variables to help explain working-class life. Rarely does the working class use the established political order for its own ends. In Katznelson's terms, "the state was treated as a cause; working-class thought and behaviour as effects" - an analysis he considers a "partial truth." The other part of this truth can be seen in the Flat Janitors' successful use of Thompson's political faction to achieve their own ends, which were usually to keep the state, in the form of the courts, at bay. In the era of injunctions, this goal was in the mainstream of AFL politics, even if the partisan involvement of the Flat Janitors was not. Recent labor histories have addressed some of these difficulties and will be used to help evaluate the import of the political cartel in which the Flat Janitors took part. It is important to add here that the scholarship addressing class formation and the state also lacks a model that adequately includes the role of capital in the urban political economy.

The concept of corporatism has the virtue of being a middle-range theory incorporating the state, labor, and capital. As used by social scientists, corporatism describes a political and economic system composed of a limited number of monopoly interests, usually representatives of capital and labor, linked to the state through a combination of mutual interest and delegated public authority. Through their relationship with the state, the interests obtain compulsory or semi-compulsory membership. Although corporatist systems can perform regulatory functions in particular industries, they typically have defined national policies on wages and prices - particularly in European industrial democracies after World War II, such as Sweden and Austria.

According to this model, the relationship with the state is critical. As Alan Cawson notes, corporatist "organizations have a privileged status with respect to government in that they co-determine public policy and are responsible for its implementation by disciplining their members to accept bargained agreements." Sanctioned by the government, either formally or informally, corporatist organizations develop a mutually interdependent relationship with the state that blurs the line between public and private spheres. Maintaining a corporatist system usually requires that all parties compromise their maximum goals for the benefits that come with being on the inside, such as predictable costs, regular wage increases, or accommodating public officials. Legitimacy is an problem for corporatist systems, since the

tury," in Working-Class Formation: Nineteenth-Century Patterns in Western Europe and the United States, ed. Ira Katznelson and Aristide R. Zolberg (Princeton, NJ: Princeton University Press, 1986), 157276.

6. Katznelson, "Working-Class Formation and American Exceptionalism, Yet Again," 53. organizations have to justify compromise to their members and their monopoly status to the public. ${ }^{7}$

While most scholars do not find corporatism in the United States, seeing the political culture as hostile to it or the institutional preconditions for it as too weak, the system of labor-management relations that emerged in Chicago's residential real estate industry after the 1917 contract had some distinct "family resemblances" to a corporatist system. ${ }^{8}$ The Chicago system arose from a condition of "mutual deterrence" between capital and labor in the industry - a condition, in Philippe Schmitter's terms, in which each could check the other from realizing fundamental goals while neither was capable of "unilateral manipulation of public authority to impose its interests indirectly through the state." ${ }^{\text {Their annual negotia- }}$ tions emerged from this standoff; through these negotiations, the union and the real estate interests defined wages and work rules that regulated and stabilized the rental market in housing and the services provided within it. Nevertheless, the hostility between the union and the real estate interests regularly threatened the negotiations to the point where Mayor Thompson's political faction began to systematically

7. Alan Cawson, "Corporatism," in The Blackwell Encyclopedia of Political Thought, ed. David Miller (Oxford: Basil Blackwell, 1987), 104-6, quote on 104. Corporatism as used in this essay corresponds more precisely to Cawson's definitions of meso-corporatism and micro-corporatism (or local corporatism), terms which he applies to political and economic activity below the national or macro levels: see Cawson, "Corporatism and Local Politics," in The Political Economy of Corporatism, ed. Wyn Grant (New York: St. Martin's Press, 1985), 126-47; Cawson, ed., Organized Interests and the State: Studies in MesoCorporatism (London: Sage, 1985); Cawson, Corporatism and Political Theory (Oxford: Basil Blackwell, 1986).

Also especially important for defining corporatism as understood here are Philippe C. Schmitter, "Neo-Corporatism and the State," in Political Economy, 32-62; Wolfgang Streeck and Philippe C. Schmitter, "Community, Market, State - Associations? The Prospective Contribution of Interest Governance to Social Order," in Private Interest Government: Beyond Market and State, ed. Streeck and Schmitter (London: Sage, 1985), 1-29.

8 . For a discussion of how the concept of corporatism applies to the United States below the macro level, see H. Brinton Milward and Ronald A. Francisco, "Subsystem Politics and Corporatism in the United States," Policy and Politics 11 (1983): 273-93; Larry C. Gerber, "Corporatism and State Theory: A Review Essay for Historians," Social Science History 19 (1995): 318-19.

For articles finding corporatism non-existent or weak in the United States see Graham K. Wilson, "Why Is There No Corporatism in the United States?" in Patterns of Corporatist Policy-Making, ed. Gerhard Lehmbruch and Philippe C. Schmitter (London: Sage Publications, 1982), 219-35; Colin Gordon, "Why No Corporatism in the United States? Business Disorganization and its Consequences," Business and Economic History 27 (1998): 29-46.

The literature on corporatism has been voluminous since Philippe C. Schmitter revived discussion of the idea with his seminal essay: "Still the Century of Corporatism?" The Review of Politics 36 (1974): 85-131. Two review essays have been particularly helpful to this author: Wolfgang Streeck, "Einleitung des Herausgebers. Staat und Verbaende: Neue Fragen. Neue Antworten?" Politische Vierteljahresschrift. Sonderheft 25 (1994): 7-21, and Gerber, "Corporatism and State Theory," 313-32. on 36 . 
intervene to help insure stability and success, a task it performed with the support of the two contenders. It is imporant to note that the government, as distinct from Thompson's organization, never officially sanctioned the system, either by passing ordinances defining its authority and powers or by setting up a formal public institution to manage it. Moreover, participants in the Chicago system did not want state involvement and the legal constraints that came with it.

The absence of the state is the main reason why this was not corporatism, despite the system's performing tasks similar to one, such as setting prices and enforcing agreements. The absence of the state also supports those critics of corporatism who argue that the institutional supports for it - in this case the state are too weak to sustain it in the United States. If corporatism does not apply, what middle-range concept does? ${ }^{10}$

It is more accurate to think of the Chicago labormanagement system as a distinct cartel. Cartels have existed in the United States both with and without the involvement of the government. A private cartel is an exclusive alliance of businesses that sets prices and divides up markets. Private cartels are inherently unstable because of the numerous incentives and opportunities for cheating, and thus detection of violators and enforcement of agreements are central problems for them. The Chicago system distinguished itself by being an alliance of businesses with a huge labor union, and thus it was not a standard private cartel. It was also unusually stable because one of the union's roles was in fact to detect and punish violators; its efficiency in performing this task stabilized the system.

Unions played this regulatory role in other industries, including coal mining, where the United Mine Workers enforced collectively bargained agreements against recalcictrant employers. A regulatory role by unions was more common, however, in those industries operating in metropolitan markets and characterized by numerous, fiercely competitive small enterprises, such as baking (especially bread), brewing, printing, and clothing manufacture. In the needle trades, for example, according to Colin Gordon, unions regulated the labor market and competition among employers, mainly because uniform pay scales elminiated wages as a tool for competitive advantage. Ironically, one of the main problems for unions in such industries was the weakness of employers associ-

10 . On the centrality of state involvement to corporatism systems, see Cawson, "Corporatism," 104; Schmitter, "Still the Century of Corporatism?" 93-94; Suzanne Berger, "Introduction," in Organizing Interests in Western Europe: Pluralism, Corporatism, and the Transformation of Politics, ed. Berger (Cambridge: Cambridge University Press, 1981), 14-16; Claus Offe, "The Attribution of Public Status to Interest Groups: Observations on the West German Case," in ibid, 136-38. For a discussion of research on corporatism at the local and national levels, see Kathleen Thelen, "Beyond Corporatism: Toward a New Framework for the Study of Labor in Advanced Capitalism," Comparative Politics 27 (1994): 114-16. ations with whom they had to deal. Because such associations were weak, "it invariably fell to the unions they bargained with to enforce not only the terms of agareements but the fealty of individual employers." This was certainly one of the roles played by the Flat Janitors' Union in the collective bargaining system that emerged in 1917 and lasted through the 1920s. ${ }^{11}$

If this system was not a typical private cartel, it was not a standard public one either. American public cartels (for example, railroads) have been managed by a federal regulatory bodies. Regulating bodies, and the federal laws creating them, have been preconditions of public cartels for some of the same reasons that corporatism finds it so hard to take root here: the American political and legal traditions contain individualistic ideas of liberty, entrepreneurial values, and market concepts hostile to managing markets and constraining liberty through collectivist institutions. Special federal legislation has been required to protect public cartels from such ideas and values codified in other federal laws such as the Sherman Anti-Trust Act of 1890 with its ban on "every contract, combination ... or conspiracy, in restraint of trade." The Chicago labor-management system discussed here, of course, lacked such legislative protection, which was the main reason it needed a political alliance to protect it. Here, the system will be called a political cartel to recognize it as an economic system with a political alliance at its core. In Chicago during the 1920s the cartel involved a huge union local playing a regulatory role, a wealthy and powerful real estate association that nonetheless lacked strong controls over its own memebers, and the city's strongest political faction, which could protect the arrangement from legal and political attack but also sorely needed the organizational and financial resources the other players in the system could provide. ${ }^{12}$

A political cartel emerged in Chicago's residential real estate industry after the Flat Janitors' successful organizing campaign between 1912 and 1917. The Flat Janitors then used the system to deflect a legal attack in the early 1920s, to substantially increase their members' standard of living, and to make themselves a power in both local politics and the Chicago labor movement.

11. John R. Bowman, "When Workers Organize Capitalists: The Case of the Bituminous Coal Industry," Politics and Society, 14 (1985): 290-92, 318; Colin Gordon, "The Lost City of Solidarity: Metropolitan Unionism in Historical Perspective," Politics and Society 27 (1999): 564-68, 573.

12. Leonard W. Weiss, "Cartel," in The New Palgrave: A Dictionary of Economics, ed. John Eatwell, Murray Milgate, and Peter Newman, 4 vols. (London: Macmillan, 1987), 1:372-74; Alexis Jacquemin and Margaret E. Slade, "Cartels, Collusion, and Horizontal Merger," in Handbook of Industrial Organization, ed. Richard Schmalensee and Robert D. Willig, 2 vols. (Amsterdam: North Holland, 1989), 1:417, 424-25. Sherman Anti-Trust Act as cited in Leonard W. Levy, et al., Encyclopedia of the American Constitution, 4 vols. (New York: Macmillan, 1986), 4:1679. 


\section{FROM UNION LOCAL, THROUGH INTEREST GROUP, TO POLITICAL CARTEL: THE FLAT JANITORS UNION FROM 1912 TO 1921}

Organizing for the Chicago Flat Janitors' Union began in 1912 under the leadership of William F. Quesse, who had been involved in an unsuccessful organizing effort from 1902 to 1905 . One of the lessons he drew from this previous experience was to concentrate on the owners of modest-sized apartment buildings spread throughout Chicago's residential neighborhoods, rather than contest with the powerful interests holding large office buildings in the Loop, the city's central business district. Such residential buildings contained from a few to twenty or more apartments, with the average being around eight to ten dwellings each. The typical janitor serviced about three buildings to support his family. ${ }^{13}$ Thus, the average flat janitor had several employers, which made organizing janitors very expensive, since the union had to deal with more than one owner to gain one member. On the other hand, any one employer had a modest stake in his janitor, because he hired a fraction of his time. Given this small investment, and faced with a persistent union, the small owners and their agents usually compromised. Those who did not filled the ranks of organizations that fought the union, legally and politically. The union engaged in constant legal battles, particularly against numerous injunctions issued by judges friendly to employers. One of these injunctions, issued by Judge Dennis Sullivan in early 1915, was so sweeping that it caught the worried attention of Samuel Gompers, who was prematurely celebrating the Clayton AntiTrust Act of 1913 as a bulwark against judicial interference in labor activity. In addition to injunctions, the union's leaders also fought any rival labor organizations that attempted to organize flat janitors. ${ }^{14}$

By 1916, after four years of grueling organizing, the union controlled enough apartment buildings to bid for a city-wide contract with the largest organizations of building agents and owners, led by the Chicago Real Estate Board. ${ }^{15}$ At this time, the union's 6,000

13. These estimates are based on William F. Quesse and C. R. Rowens to "Gentlemen" at the American Federation of Labor in Washington, DC, Jan. 27, 1915, Chicago Federation of Labor Papers, Chicago Historical Society (hereafter CFL Papers), box 3, folder 18; [William F. Quesse], "To the Public: Tenants of Apartment Buildings in Particular, as well as Landlords and Real Estate Agents," (Chicago: Chicago Flat Janitors' Union, n.d.), Service Employees International Union (SEIU), Local 1, unprocessed material, Archives of Labor and Urban Affairs, Wayne State University (hereafter Archives, Local 1), 3; Chicago Daily Tribune (hereafter Tribune), Dec. 16, 1918; Chicago American, Jan. 2, 1919; Chicago Herald and Examiner, Jan. 2, 1919.

14. Jentz, "Labor, the Law, and Economics," 417-27.

15. At this time the Chicago Real Estate Board represented building agents who managed property for owners. In 1913, the Board represented 803 agents, in 1919, 1400 (The Economist [Chicago], Dec. 20, 1913; Tribune, Nov. 17, 1919). The Board competed members comprised well over half of all flat janitor's in the city. Standing on this strong foundation, the union initiated a period of intense maneuvering in November 1916 by demanding a contract that would begin January 1 . In response, the real estate organizations threatened to expel janitors from the apartments they received as part of their compensation, while the Flat Janitors called selected strikes against owners refusing to hire union janitors. Faced with no heat during Chicago's severe winter, tenants across the city organized to take over building services. The union demanded that one militant owners group be expelled from the negotiations; it had sponsored legal challenges to its organizing since 1914, including the one that produced the Sullivan injunction. After weeks of threats and recriminations, and as the deadline of January 1 approached, this controversial owners group was pushed out of the negotiations. ${ }^{16}$

The agents and owners then made a new demand that the wages of janitors be prorated according to the varied rents charged in different parts of the city. One of the biggest complaints of building owners was that the uniform city-wide wage scale demanded by the union would be unfair to those in less desirable neighborhoods earning less money from their buildings. This complaint was not unusual. Such divisions among more and less profitable businesses typified, for example, the coal industry when it negotiated labor contracts with the United Mine Workers. The coal industry's final agreement included a provision for "competitive equality" that allowed mine owners with less profitable mines to pay less wages than the norm. ${ }^{17}$ Needing a similar provision to accommodate their members, the Chicago real estate organizations demanded a "sliding scale" of wages; but by accepting it the union would have to give up its cherished principle of equal pay for equal work. It had always wanted wages determined simply by the number and size of apartments serviced. On this point the union compromised. ${ }^{18}$

With accommodations made on both sides, an agreement fell into place. The janitors received a wage increase, averaging about 7 percent, and better working conditions. The sliding scale was agreed to, but precise details were postponed to subsequent negotiations, since the issue was so controversial and complex. An arbitration mechanism was set up to resolve disputes with a mediator agreed to by both parties. The union could not strike or picket a building while a dispute was under arbitration. Such arbitration mechanisms had been a goal of the janitors since they began organizing in 1902; and the procedures were patterned after similar ones proposed in the

with other organizations representing the interests of the real estate industry; see below.

16. Jentz, "Labor, the Law, and Economics," 427-28.

17. Bowman, "When Workers Organize Capitalists," 298.

18. Jentz, "Labor, the Law, and Economics," 428-29. 
Chicago construction industry and elsewhere in the last two decades of the nineteenth century. Finally, and most important for the Flat Janitors' Union, the owners agreed to hire only its members: the Flat Janitors had a closed shop, a provision that meant the end of rival unions. The union achieved its victory with fewer than 200 of its 6,000 members going out on strike. There were two keys to the union's success: it had organized most of the flat janitors in the city before it initiated negotiations for a contract; and it operated in an industry with a metropolitan market. In such a market it was feasible for a union as strong as the Flat Janitors to protect unionized employers from nonunion competition, creating more room to maneuver for both parties in labor negotiations. ${ }^{19}$

The 1917 contract came just a few months before the United States entered World War I. This conjuncture of events had significant import for the union leaders' ability to transform their organization into one of the key interest groups in the city, a status it achieved by the early 1920s. As an interest group acting beyond the narrow confines of labor contracts and within the power blocs that ruled Chicago - the Flat Janitors' Union was able to shape the political and economic environment in which it operated. In so doing, it performed intermediary functions typical of organizations in corporatist systems, such as shaping and articulating the interests of the membership, making and enforcing policies with broad public import, and bargaining with institutional opponents and the government for whole sectors of an industry, although the Flat Janitors dealt with the city's most powerful political organization, not with government agencies. ${ }^{20}$

Building a politically powerful interest group demanded much of the union's members. Over twothirds of them were immigrants working in one of the lowest status jobs in the city. Like other unskilled workers in the United States, these men moved about incessantly, from job to job and city to city; and thus they had little commitment to particular institutions and lacked the persistence in one place required for political participation. The 1917 contract made janitorial jobs more desirable and thus worth maintaining. The union's leaders also used the war effort to

19. Ibid., 425-26, 429-30; on unions protecting unionized employers see Bowman, "When Workers Organize Capitalists," 290, 297-301, 317-19. Arbitration of labor disputes was much discussed in Chicago and Illinois after violent class conflict during the Pullman strike of 1894. A State Board of Arbitration was established in 1895, during the administration of governor John Peter Altgeld. On the divisive experience of Chicago carpenters with arbitration, see Richard Schneirov and Thomas J. Suhrbur, Union Brotherhood, Union Town: The History of the Carpenters' Union of Chicago, 18631987 (Carbondale, IL: Southern Illinois University Press, 1988), 54-55, 89-90.

20. Such intermediary functions are well summarized by Wolfgang Streeck and Philippe C. Schmitter as the "logic of membership" and the "logic of influence"; see Streeck, "Einleitung," $12-15$. change the way the members thought about themselves. The Flat Janitors' Union enthusiastically joined patriotic drives to buy war bonds, and it trained its members to burn scarce coal more efficiently to contribute to the war effort. The union also required all foreign-born members who were not citizens to start the process of naturalization. These developments helped the immigrant members build attachments to the country, their jobs, and the union bonds which made them more reliable trade unionists and more active citizens whom the union could involve in political campaigns. ${ }^{21}$

Different causes produced similar results for the one-fifth of the membership composed of AfricanAmericans. Blacks were less transient because racial prejudice pushed them to keep the few jobs they could get. The Flat Janitors' policy against racial, ethnic, and class prejudice made keeping janitorial jobs in Chicago even more desirable. In 1916, Quesse wrote,

We are ... composed of all creeds, colors and nationalities, and do not allow anyone to use any prejudice in the organization against each other, for when we first organized we had everything in our organization from an exbank cashier to a common laborer. ${ }^{22}$

The union's goals help explain this highly unusual policy: Quesse and his fellow leaders wanted to control Chicago's labor market in flat janitors, and thus they had to organize the large number of African American janitors. Nevertheless, the leaders might have followed the typical path of organizing a separate black local; but they were as strongly opposed to any rival organizations of janitors as they were to racial and ethnic prejudice. African American janitors responded to the union's policies not only by joining but also by taking leadership positions. In 1919, one-third of the Flat Janitors' executive board was black. ${ }^{23}$

While the 1917 contract made the union membership even more attractive to African Americans, World War I transformed the black community in Chicago, increasing it dramatically and mobilizing it politically. By stopping immigration, the war helped stimulate the great migration of African Americans out of the South to jobs in the North's booming war economy. Already possessing an experienced political leadership, black Chicago grew enormously within the increasingly dense confines imposed by segregation. Racial tensions grew, but so did the political signifi$4-15$.

21. Jentz, "Citizenship, Self-Respect, and Political Power,"

22. [William F. Quesse], "History of the Organization: Why and How the Flat Janitors of Chicago, Illinois were Organized," in Official Year Book (1916) (Chicago: Chicago Flat Janitors' Union Local 14332, 1916), Archives, Local 1, n.p. $13-21$. 
cance of black Chicago, particularly to politicians like Mayor Thompson, who was first elected in 1915 with substantial support from African American voters. Chicago's expanding Black Belt became an integral part of Thompson's coalition. The substantial African American role in the Flat Janitors' Union made it easier for the organization to form an alliance with Thompson that lasted throughout the 1920s. ${ }^{24}$

World War I did more than bring blacks to the North and enforce patriotism on immigrants. The Wilsonian liberalism used to justify America's role in the war provided Quesse and his fellow leaders with an opportunity to define democracy and Americanism in ways useful to the union. It was easy to link the war to make "the world safe for democracy" to the union's own struggle to "gain a little democracy in the field wherein we earned our livelihood." 25 This rhetorical tactic was adopted by numerous unions during World War I. The war effort legitimated importing a political concept like democracy into the workplace along with the patriotic drives to buy war bonds and burn less coal. Bringing democracy to work affected more than relations with employers. For years, Quesse had promoted a civic ethic of selfrespect and citizenship among the janitors; the war helped him enhance both while linking the union's demands for higher wages and better working conditions to Americanism. ${ }^{26}$

Both the country and the union were fighting for the "American way," which Quesse interpreted to include a higher standard of living for his members. Drawing deeply from the AFL's ideology, Quesse defined the "American Standard" as more than better apartments and higher wages: it also meant respectability in the way janitors interacted with other people, in how their families lived, and in their civic involvement. As he said, "We are an organization of gentlemen, doing business in a courteous way." Quesse expected to be treated the same way by employers and tenants, just as he demanded a higher standard of behavior from his members. After winning the 1917 labor contract, the union set out to get "a better class of workmen in our organization," and this included men who treated their wives with greater respect. For example, when union leaders found pregnant wives doing janitorial work while the janitor was drinking in a saloon, Quesse actively set the organization to stopping such behavior. In doing

24. Ibid., 13-14; Douglas Bukowski, "Big Bill Thompson: The 'Model' Politician," in The Mayors: The Chicago Political Tradition, ed. Paul M. Green and Melvin G. Holli, rev. ed. (Carbondale, IL: Southern Illinois University Press, 1995), 62-63, 65-66, 70-71.

25. William F. Quesse, "The Past Year," Official Year Book (1919) (Chicago: Chicago Flat Janitors' Union Local 14332, 1919), Unprocessed Service Employees International Union (SEIU) Collection, SEIU Accession No. 1542, Box 267, Shipment Date, Sept. 1997, Archives of Labor and Urban Affairs, Wayne State University (hereafter Unprocessed SEIU Collection, Wayne State), 35, 37.

26. Jentz, "Citizenship, Self-Respect, and Political Power," 1021; McCartin, Labor's Great War, 104-6. so, he probably drew heavily on his strong Roman Catholicism to define what it meant to be a husband and father. The union was creating the economic possibility for respectable family life, while at the same time defining it for the members; and such family life was at the core of the union's vision of the American standard of living. The opposite of the American standard was a kind of bondage, and the union justified itself to the members as their liberator from this degraded state. This message resonated with members who had experienced substantial benefits following the 1917 contract. Reinforced with fraternal ritual, such as secret passwords, the bonds forged between the members and with the leadership during the war years survived ethnic and racial tensions as well as legal attacks on the union in the 1920s. ${ }^{27}$

Quesse and his fellow leaders used the opportunities provided by the 1917 contract and World War I to mold an interest group out of class sentiments, fraternal ritual, AFL ideology, wartime patriotism, and Wilsonian liberalism. They acted like "interest entrepreneurs," in the words of Wolfgang Streeck. ${ }^{28}$ Their achievement illustrated a point made by students of corporatism - that the leaders of interest groups do not represent the previously formulated opinions of their members so much as actively mold those opinions in the process of defining the culture of their organization. ${ }^{29}$ The culture of the Flat Janitors' Union performed some of the same functions that Dorothy Sue Cobble found in the waitress's unions she studied. In both cases, their organizational culture sustained solidarity, gave members the self-confidence to enforce contract provisions and work rules, and created a pride in their occupation as a craft. Backed by detailed work rules, this pride improved the quality of their work, making them more desirable employees. The result for the waitresses and the janitors was, in Cobble's terms, "occupational unionism," which

27. [Quesse], "History of the Organization," 1916 Year Book, n.p.; for similar statements as well as the janitors' conditions described as a kind of bondage see also [Quesse], "To the Public," $1-3$. On citizenship and respectability, see Jentz, "Citizenship, SelfRespect, and Political Power," 10-21. On Quesse's Catholicism see speech of Father Malloy in Federation News (Chicago), Feb. 26, 1927. On the broad meaning of the American Standard, including the definition of slavery and freedom in relation to it, see Lawrence $B$. Glickman, A Living Wage: American Workers and the Making of Consumer Society (Ithaca, NY: Cornell University Press, 1997), 78-87. For the terms slavery and the American Standard used to describe the janitors' struggles and achievements, see John J. Kearney to Governor Len Small, Jan. 30, 1924, filed with Illinois Parole and Pardon Board, "William F. Quesse, et al.," Record Series 403.2, Illinois State Archives (hereafter Pardon Hearings); Victor Olander, testimony, official transcript, Pardon Hearings, 87-88.

28. Streeck, "Einleitung," 13.

29. Ibid., 9-15; Streeck and Schmitter, "Community, Market, State - and Associations?" 19-20, 27; Schmitter, "Neo-corporatism and the State," 35-38; Alan Cawson, "Is There a Corporatist Theory of the State?" in Democracy and the Capitalist State, ed. Graeme Duncan (Cambridge, England: Cambridge University Press, 1989), 239-41; Roger King, "Corporatism and the Local Economy," in Political Economy of Corporatism, 205-7. 
adapted the model of craft unions to fit low-skilled occupations in industries characterized by numerous small, dispersed employers. In such industries, the culture of the organization, not the work site, had to provide the locus of solidarity. ${ }^{30}$ For the janitors, this organizational creativity produced more than another big union local. Huge, disciplined, and brilliantly led, the Flat Janitors' Union formed a powerful interest group able to maneuver at the center of the city's politics and economy. And, as it maneuvered in Chicago's power centers, it became part of, as it helped create, a political cartel.

The negotiations for the 1920 and 1921 labor contracts illustrated how this cartel evolved. Late in 1919, the Flat Janitors announced their demands and fixed a deadline of November 27 for the employers who had broken the existing contract. The majority of owners who had kept the contract had until January 1. There was widespread dissatisfaction among owners with the current contract because postwar inflation was automatically increasing janitors' wages the result of the "sliding scale," which tied the wage rate to the income from buildings. A bomb explosion at the apartment building where Quesse lived heightened tensions. Shortly afterwards, Quesse walked out of negotiations with the building owners when they rejected the Flat Janitors' wage demands. The owners called for the aid of tenants in running struck buildings, threatened to throw striking janitors out of their apartments, and assessed owners to build a fund to resist the anticipated strike. As tensions mounted, negotiations became more serious. By December 7, the union and owners had reached an agreement raising wages 10 to 20 percent and expanding the closed shop to cover not only janitors but all people employed by the owners, a provision mainly affecting the building trades, who were close but suspicious allies of the Flat Janitors' Union. The new contract also continued the central features of earlier contracts, including the arbitration mechanism. ${ }^{31}$

This 1920 agreement covered three-fourths of all apartments in the city, "leaving the janitors to deal with the other owners," in the words of the Tribune. ${ }^{32}$ When the union struck the holdouts' buildings after January 1, Ivan O. Ackley, a leader of the Chicago Real Estate Board, said,

30. Dorothy Sue Cobble, Dishing It Out: Waitresses and Their Unions in the Twentieth Century (Urbana: University of Illinois Press), 137-48; Cobble, "Organizing the Postindustrial Work Force: Lessons from the History of Waitress Unionism," Industrial and Labor Relations Review, 44 (1991): 419-35.

31. Tribune, Nov 17, 1919, Dec. 1 and 3, 1919; Chicago Labor News, Dec. 16, 1918, Nov. 14 and 21, 1919, and Dec. 7, 1919; Pat Cooper, "History of the Building Service Employees International Union," part of the original ms. of A Need For Valor, Unprocessed SEIU Collection, Wayne State, SEIU Accession No. 1542, Box 85, Shipment Date, Sept. 1997. On relations between the Flat Janitors and the building trades see Jentz, "Labor, the Law, and Economics," 417.

32. Tribune, Dec. 7, 1919.
The owners affected by the strike are isolated men who handle their own buildings and are not represented in the agents' association .... Any man who failed to sign the agreement is not keeping faith with the association. The men who have strikes on their shoulders have them on their own responsibility. ${ }^{33}$

In other words, Ackley was glad to throw the recalcitrant owners to the Flat Janitors. In this year, at least, the holdouts did not put up much of a fight: a short strike of 250 janitors - out of over 6,000 in the union forced them into line. ${ }^{34}$

These events illustrated how the Flat Janitors helped the real estate organizations discipline their constituency, and not only by striking against the holdouts. As Ackley's statement reveals, the recalcitrant owners did more than not sign the contract: they also refused to hire a building agent or join one of the agents' associations negotiating with the janitors. At this time, the Chicago Board of Real Estate was composed of agents who managed buildings; the organization began to directly recruit property owners within the next few years. Rejecting both agents and representation by their associations, the holdouts should not, in Ackley's opinion, receive the benefits that the agents' associations provided, including protection from the Flat Janitors. These recalcitrant owners were in an analogous relation to the real estate associations as non-union janitors were to the union, and they were dealt with similarly. Ackley's frustration with the recalcitrants may have stemmed from considerable efforts to recruit them earlier. In the previous year, the real estate associations had competed among themselves to expand their memberships. The Chicago Board of Real Estate dropped its initiation fee from $\$ 200$ to $\$ 50$ in this competition. The Board's leadership in negotiating the 1920 contract with the Flat Janitors helped consolidate its preeminence among the city's real estate organizations. As the Flat Janitors' Union struggled to organize new members and win better contracts, it was also stimulating the organization of the industry's numerous capitalists into comprehensive associations with which it could negotiate city-wide agreements. ${ }^{35}$

The next year's negotiations were so difficult that the city's political leadership intervened, beginning a long-term involvement in the real estate industry's labor relations. This involvement marked the final stage in the evolution of the cartel. After the 1917

33. Chicago American, Jan. 3, 1919. Although Ackley's official position at this point was unclear, he was active in the Chicago Real Estate Board in the 1910 s and 1920 s, at one point serving as president.

34. Chicago Herald and Examiner, Jan. 2 and 3, 1919.

35. On the competition among real estate associations, see Tribune, Dec. 19, 1918. On unions prompting capitalists to organize, see Colin Gordon, New Deals: Business, Labor, and Politics in America, 1920-1935 (Cambridge: Cambridge University Press, 1994), 87127; Bowman, "When Workers Organize Capitalists," 294-97; Wilson, "Why Is There No Corporatism in the United States?" 232-35. 
contract victory, Quesse had taken the Flat Janitors into Mayor Thompson's coalition. The union's multiethnic and interracial membership fit well with Thompson's strong constituencies among African Americans and "old" immigrants - Irish, Germans, and Scandinavians. Thompson also needed the union's unusual organizational strength. Although Big Bill was strong on political showmanship, his weakness in organizational skills meant that his supporters remained a faction unable to survive without his leadership. Thus, Thompson did not build a genuine political machine, the honor for which went to the Democrats in the 1930s. Thompson's weakness, particularly in precinct organization, was the Flat Janitors' opportunity, for the union had members in every ward who could put up signs, talk to voters, help people to the polls - the grassroots activities needed in American elections. The Flat Janitors' Union was a ready-made, city-wide precinct organization with a staff of over $6,000 .^{36}$

One result of Quesse's political alliance was the arbitration of the 1921 contract by William Fitzmorris, Big Bill's newly appointed Chief of Police. A political insider, Fitzmorris had previously run the mayor's office. With the annual negotiations stalemated, the Flat Janitors and the real estate interests agreed on Fitzmorris as arbitrator; after appropriate deliberations, he extended the 1920 contract for another year with only modest modifications. Although the union did not get the wage increases it had demanded, Fitzmorris's decision was in fact a major union victory, won in the face of successful open-shop campaigns across the nation. By preserving the Flat Janitors' wartime gains, Fitzmorris's arbitration helped the union's leaders justify to the members the political exertions demanded of them as well as the compromises needed to obtain the agreement. Fitzmorris's involvement also helped sanction to the public the privileged roles which the Flat Janitors' Union and the Chicago Board of Real Estate had claimed in determining the price of apartment housing in Chicago. Although new and unstable, the system was clear, especially to outsiders, who hurled accusations of corruption. ${ }^{37}$

36. George Schottenhamel, "How Big Bill Thompson Won Control of Chicago," Journal of the Illinois State Historical Society 45 (1952): 30-40; Douglas Bukowski, Big Bill Thompson, Chicago, and the Politics of Image (Urbana: University of Illinois Press, 1998), 1067, 113-14, 134-35, 177-91; Bukowsky, "Big Bill Thompson," 62 , 76; Jentz, "Citizenship, Self-Respect, and Political Power," 4-21; Christopher K. Ansell and Arthur L. Burris, "Bosses of the City Unite! Labor Politics and Political Machine Consolidation, 18701910," Studies in American Political Development 11 (1997): 23.

37. On Fitzmorris and his arbitration of the 1921 contract, see [Quesse], "To the Public," 5; The Republican (Chicago), Apr. 6 , 1918; Tribune, Dec. 17, 18, 19, 28, 1920. On the national economic situation and the open-shop campaigns, see Foster Rhea Dulles and Melvyn Dubofsky, Labor in America: A History, Fourth Edition (Arlington Heights, IL: Harlan Davidson, 1984), 222-32. On both the relation between leaders and followers in corporatist institutions as well as public involvement in corporatist systems, see Streeck, "Ein-
Much of what accusers called corruption, particularly the union's levying of fines, resulted from the Flat Janitors' role in the cartel. Cartels among businesses have always had trouble enforcing their agreements, and the more participants they have the greater the problems. With thousands of members and weak internal sanctions, the Chicago real estate associations actually delegated enforcement to the union, although, of course, they never publicly acknowledged this. (As noted earlier, this situation was unusual but not unique: the United Mine Workers performed a similar function in the bituminous coal industry.) The Flat Janitors' Union agreed to carry the weight of enforcement, since its members were the most likely to suffer from contract violations. For enforcement to be successful, the union's members had to be responsible enough to know the contract, insist on its enforcement in the face of owners and agents, and complain to union officials if it was violated - tasks requiring assertiveness, tact, and the selfrespect that Quesse talked so much about. If the janitor could not handle the problem, the union's business agents had to step in using arguments and threats to gain compliance. And, if all else failed, the union called a strike against the building. Its pickets not only stopped janitorial services but also the teamsters' deliveries of coal, ice, milk, beer, and groceries. $^{38}$

Given the thousands of apartment building owners, the union was always striking buildings across the city, although Quesse never took the whole local out on strike. A strike of all the janitors would have been very costly and would likely have brought intervention by public authorities against a threat to the wellbeing of so large a portion of the citizenry. To carry out the day-to-day strikes against particular owners the union simply used some of its own employees as full-time pickets, a task that provided an entry level job with the organization. If the strike ended with a union victory, the Flat Janitors' Union imposed a fine on the owner. To most owners the fine was simple extortion and its imposition by the union an affront, despite the fact that the union was enforcing an agreement negotiated with associations to which practically all the owners belonged. The union, of course, saw itself as carrying most of the burden of maintaining the annual agreement and thus felt justified in recovering its costs, as well as getting the benefits owed its members, including back wages owed. In these cases, what the owners - and practically all

leitung," 9-10, 15; Schmitter, "Neo-corporatism and the State," 43-44, 57-58; Cawson, "Corporatism and Local Politics," 127; Streeck and Schmitter, "Community, Market, State - and Associations?" 19-20; Berger, "Introduction," 14-16; Offe, "Attribution of Public Status to Interest Groups," 123-25, 136-39.

38. On policy formation and enforcement see Streeck, "Einleitung," 15-19; Cawson, "Corporatism," 104; Weiss, "Cartel," 37274; Jacquemin and Slade, "Cartels, Collusion, and Horizontal Merger," 417, 425. For a typical strike see Jentz, "Labor, the Law, and Economics," 420-23. 
newspapers - called corruption was the enforcement of a collectively bargained labor agreement sanctioned by the city's most powerful political faction. ${ }^{39}$

More was meant by the charges of corruption, however. Union officials were accused of personally taking the money paid in fines, and the union was charged with multiple forms of coercion. If Quesse took money for himself, he did not spend it on conspicuous consumption. During the formative years of the union between 1912 and the early 1920s, Quesse's family lived in several apartments in a South Side neighborhood anchored by Corpus Christi Roman Catholic Church, where his children attended school. Populated by families of skilled workers and small proprietors, the area became part of Chicago's Black Belt while the family lived there. When Quesse died in 1927, at the age of forty-eight, his family lived in Rogers Park, a middle-class neighborhood on the North Side. He left an estate that allowed his family to maintain a comfortable middle-class life. ${ }^{40}$

39. Typically, the newspapers reported the fact that the pickets were union employees as a sign that the strike was not genuine

40. Between 1913 and 1923, the Quesse family lived at several different addresses on Calumet, Prairie, and Indiana Avenues in a five block area at the southern end of the Third Ward between 47th and 48th Streets.

The Probate Court determined that Quesse's estate was worth $\$ 161,449$, which, in 1998 dollars, would amount to $\$ 1,512,777$. The Court agreed that the estate should support his wife and two children with $\$ 9,000$ annually, the equivalent of $\$ 84,330$. Quesse's wealth was primarily in the form of mortgage bonds, stock in utilities, and real estate, including two modest-sized farms, one in Wisconsin and one in Florida. On his estate consult "Last Will and Testament of William F. Quesse," "Appraisement of Widow's and Child's Award, "Inventory," and "Petition for Partial Distribution and Payment of Widow's Share," in Probate Records of William F. Quesse, deceased Feb. 16, 1927, Clerk of the Circuit Court of Cook County Archives, Chicago, Illinois. The estate's cash value was converted using "What's a Dollar Worth? CPI Calculation Machine," Woodrow: Federal Reserve Bank of Minneapolis, http: / woodrow. mpls.frb.fed.us/economy/calc/cpihome.html (Mar. 18, 1999).

By the prevailing standards of American society, either then or now, janitors were not supposed to accumulate that much wealth even if they organized and managed large institutions. The contemporary press concluded that his estate was prima facie evidence that "Czar Quesse" had extorted money for his own gain. William Z. Foster, America's most prominent communist, assumed the same thing, even while conceding that his union had "undeniably" improved the janitors' "hours, wages, and working conditions." Such conclusions were not as obvious as they seemed. Quesse, for example, had won a settlement of $\$ 10,000$ in a civil suit in 1913 brought against two building owners who had "arrested" him on their own while he was organizing their janitors. If he had invested the $\$ 10,000$ as he usually did in mortgage bonds, stock in utilities, and real estate, it would have constituted a significant proportion of the $\$ 161,499$ he was worth in 1927 , especially given the economic boom of the 1920s. Such considerations do not, of course, prove that he was innocent either. One thing was clear, the value of his estate did not threaten his standing among the janitors, who likely saw in his wealth and power an embodiment of what the union could do for men of their lowly station in life. See William Z. Foster, Misleaders of Labor (n.p.: Trade Union Educational League, 1927), 179-80; Foster reported that Quesse was worth $\$ 200,000$; on the 1913 law suit see Superior Court of Cook County, Declaration, Case No. 13S305393, William F. Quesse v. Franklin Hardin and Ella M. Hardin, Dec. 1913, Clerk of the Circuit Court of Cook County Archives, Chicago, IL.
Charges of coercion were easier to establish, depending on what was meant. In protracted strikes the union resorted to sabotage against the struck buildings. This violence against property had an almost ritual quality. When a building owner hired a non-union janitor late in 1914, union representatives sought out the man and demanded that he quit his job or join the union by the next day. When they returned and found that he had not complied, they said, "'Well, we will do ours then.'” That included picketing, leaving a furnace door open so coal gases filled the building, dumping garbage in the vestibule, and setting off "stink bombs." Such tactics during strikes were typically part of a tit-for-tat escalating cycle of violence. Two bombings at the apartment buildings where Quesse's family lived were extreme examples. More commonly, the owners hired private guards who harassed and sometimes beat up the union's pickets. Or, quite often, sympathetic city police performed the same service for the owners free of charge. Conflicts between labor and capital in Chicago had been, and would remain, permeated with violence; and the Flat Janitors delivered as well as received in this rough action. While none of this will surprise students of Chicago history, it is most important to note how the union's use of coercion fit with its role in the cartel. In using sabotage, the union was doing the dirty work of enforcing the annual labor agreement for the real estate associations as well as itself, and, indirectly, for Big Bill Thompson too, a substantial real estate owner himself. Thompson relied on both the union and the real estate interests to help sustain his organization, as well as manage the market in rental housing through the cartel. ${ }^{41}$

The issue of coercion also pertained to rival unions and power relations within the organization. To preserve its closed shop, for example, the union had to insure that there were no rival labor organizations, much less owners hiring non-union labor. One group of janitors claimed to be just a mutual benefit society, but the union thought otherwise and picketed the building where the president worked until he resigned from the organization or was fired by his employer. The Flat Janitors also opposed the formation of an African American local in the early 1920s, and rumors of violence surrounded such incidents. The rumors, in fact, helped keep the members in line, as well as building owners. In 1915, candidates running against Quesse and the other sitting leaders of the union claimed that they were beaten up by "sluggers," or hired thugs. Despite union denials, the rival candidates got an injunction in their favor, but lost their political bid anyway. Quesse probably saw this particular slate of candidates as the officers of a former rival local tying to take over his new union. ${ }^{42}$

41. On the 1914 incident, including the quotation, as well as on the larger subject of violence in the union's history, see Jentz, "Labor, the Law, and Economics," 419-22.

42. Ibid. 426-27; Jentz, "Citizenship, Self-Respect, and Political Power," 14. 
In these cases, the Flat Janitors were acting like participants in corporatist systems anxious to preserve their special status as sole arbiters of their domains. Coercion was probably more frequently required to maintain the cartel than would otherwise have been the case in a corporatist system because the cartel lacked the public legitimacy such arrangements obtain from official sanctioning by the state. The Flat Janitors were also acting like an institution under siege, a common state for American trade unions, and particularly for this union. Steve Fraser has written that,

\begin{abstract}
Frequently formed under beleaguered conditions, it's hardly a surprise the union executive is vested with extraordinary powers, not dissimilar to a nation under siege and prone to the same suspension of full democratic liberties. (After all, the union shop is a kind of compulsory form of solidarity.) Except that in America there's hardly ever a truce, much less a lasting peace, in the war against unions. ${ }^{43}$
\end{abstract}

The legal attack on the union in the 1920s illustrated why the Flat Janitors were always in combat readiness.

The political cartel that had emerged by the early 1920s provided a platform of power that Quesse used to advance the union in Chicago's economy and politics. He did more than make the union an organizational base for Thompson's political faction. He also testified at City Council hearings on zoning and building codes, promoting public health issues such as banning outdoor privies as well as providing better apartments for janitors. He worked with public officials trying to reduce air pollution, the "smoke menace," by training janitors to burn coal more efficiently. In such ways, he built alliances with reform groups, which sometimes aided the union's organizing efforts. Quesse was by no means unique in this regard; unions and political bosses, including Big Bill Thompson, have proven adept at supporting selected progressive causes for their own ends and thus have contributed to urban liberalism. More important, Quesse's promoting of reform interests shaped a more positive public perception of the union, which helped it justify its special status in the cartel. ${ }^{44}$

Of equal importance, Quesse made the Flat Janitors a pillar of the Chicago labor movement. Historian Barbara Newell has argued that three types of

43. On power relationships and coercion in corporatism systems see Streeck, "Einleitung," 10-11; Schmitter, "Still the Century of Corporatism?" 101; Steve Fraser, "Is Democracy Good for Unions?” New Labor Forum 3 (1998): 78.

44. In the late 1920s, the Flat Janitors cooperated with the Women's Trade Union League, a predominantly middle-class reform group, to organize female hospital workers; see Building Service Employees International Union, "Cause and Effect of Organized Labor," in Papers of the Women's Trade Union League, Collection VIII, Reel 1. On unions and political machines supporting progressive causes, see Brody, "Labor Movement," 718. On the relation of corporatist organizations and broader public interests, see Streeck, "Einleitung," 15-16. unions - teamster, building trades, and building service - formed a stable "triumvirate" at the core of Chicago labor. Most prominently represented by the Flat Janitors, the building service workers were the last of the three to establish a stable power base. All three types of unions used solidarity and political power to schieve dominance in particular metropolitan markets. Such markets had special characteristics well defined by Richard Schneirov:

(1) a relative inability of employers to substitute capital and machinery for labor inputs, (2) extensive capital at risk per worker, (3) vulnerability of capital to damage or short-term disruption by workers, and (4) a secure market for a firm's products.

Operating in such a market, the apartment rental industry had all these qualities, plus thousands of owners, making it relatively "immune from tendencies toward mass production and corporate ownership." 45

Contrary to the stereotype of American labor before the 1930s, the power and stability of these Chicago unions did not depend on organizing pockets of skilled craftsmen, but rather on controlling metropolitan labor markets in which they tried to protect unionized businesses from non-union competition. Colin Gordon has found examples of such "metropolitan unionism" in the Progressive Era through World War II, noting that they constituted "important episodes in the history of American labor and in the history of American cities." ${ }^{46}$ From the core formed by teamster, building trades, and building service unions, the Chicago labor movement made forays into closely related industries, such as hotels and restaurants, and then into the mass-production manufacturing sector - the packinghouses and steel mills where the movement's organizing campaigns were often beaten up, both literally and figuratively. Nonetheless, these unions operating in metropolitan markets provided a sustaining organizational base.

\section{LEGAL ATTACK AND POLITICAL COUNTERATTACK: THE FLAT JANITORS AND CHICAGO POLITICS IN THE 1920S}

The 1920s severely tested both the cartel and the Flat Janitors' Union, which was almost destroyed by a legal attack. This legal offensive pushed the union into even more political activity, and the union's counterattack revealed the contours of the cartel in greater clarity. In the broadest sense, the battles with employers and the courts were conflicts over redefining the "grammar of rules," in Katznelson's terms, regulating the exercise of power by a new institution in civil society, the Chicago Flat Janitors' Union.

The national open-shop campaign after World War

45. Barbara Warne Newell, Chicago and the Labor Movement: Metropolitan Unionism in the 1930s (Urbana: University of Illinois Press, 1961), 209-11, 225; Schneirov, Labor and Urban Politics, 315. 46. Gordon, "Lost City of Solidarity," 565. 
I profited from the first Red Scare and from Attorney General A. Mitchell Palmer's raids against the Left. As employers tried to roll back labor's wartime gains, an unprecedented wave of strikes swept the country. The New Republic caught the mood of the moment:

There is a general disposition among the employers, the politicians and the press to treat the labor unrest as a culpable and sinister rebellion - as an autocratic anti-social demonstration of power which the American nation ... must suppress at any cost. They cherish this bellicose and irreconcilable attitude of mind as patriotic and public spirited.

The magazine emphasized the press's role in what quickly became a national campaign: "It is as profitable to argue with the great majority of American newspapers on a contemporary labor controversy as it is to argue with a brass band." ${ }^{47}$

Less well-known than the national open-shop campaign were similar but distinct efforts at the state and local level, which, of course, drew strength from the national movement. The Chicago campaigns were initiated and led by prominent businessmen and professionals; describing themselves as "citizens," their campaigns usually began as attacks on corruption in Chicago's politics and economy. Typically, however, the campaigns concentrated on corruption in the labor movement, using the power of the courts to attack, not simply particular corrupt trade unionists, but also unions as institutions - one of which was the Chicago Flat Janitors' Union.

Quesse had been familiar with business's use of the police and courts since at least 1912, when two property owners - not the police - had "arrested" him during an organizing effort and took him to the police station, where he was held for three days before arraignment. Now, in the 1920 s, business's use of the criminal justice system achieved new levels of sophistication. The Chicago Crime Commission and the Dailey Commission were two cases in point. Organized during the war by a committee of businessmen concerned by the level of crime in Chicago, the Crime Commission swung into action soon after the armistice. Energy and organizational talent came from the Chicago Association of Commerce, an elite business association, which called for action against crime in December 1918. Moving quickly, the Crime Commission formed numerous study committees and called on the American Protective League, a vigilance group organized to enforce loyalty during World War I, to continue its activities in Chicago after

47. Elis W. Hawley, The Great War and the Search for a Modern Order: A History of the American People and Their Institutions 1917-1933, 2d ed. (New York: St. Martin's Press, 1992), 39-42; Dulles and Dubofsky, Labor in America, 220-32; Savel Zimand, The Open Shop Drive; Who is Behind It and Where is It Going? (New York: Bureau of Industrial Research, 1921); "Americanism in the Present Crisis," The New Republic, Nov. 12, 1919, 302-4. the war. In December 1920, the Crime Commission held a confidential meeting of government lawenforcement agencies, several business groups, including the Chicago Real Estate Board, and members of the clergy. The day after this meeting six additional judges were assigned to the criminal court to speed its proceedings. By the fall of 1921, the Crime Commission used its money and legal expertise to aid the prosecution of the top ten leaders of the Flat Janitors' Union. By this time, the Commission had became a "centralized power in the administration of justice" in Cook County. The Commission pursued the union into $1924 .{ }^{48}$

The history of the Dailey Commission paralleled that of the Crime Commission. During and especially after World War I, the Illinois Legislature received numerous complaints about the inability of the Chicago construction industry to respond to the demand for housing, thus raising rents and home prices. Several construction unions, for example, colluded with manufacturers and contractors to only use millwork produced by a local companies, as long as the businesses involved hired only union labor. Raising prices, sometimes astronomically, such arrangements dated back to the 1890s. The Legislature established the Dailey Commission to investigate these practices, and it held public hearings in Chicago from late March through June 1921. The press reported the hearings extensively in ways that inflamed public opinion against labor. The Commission considered such "organized public sentiment" a precondition for the success of its endeavors, and in its final report it even thanked seven Chicago newspapers for "their wholehearted co-operation." Its report also admitted that "the prosecution of labor leaders has been more vigorous than that of others equally guilty," that is, building contractors and manufacturers; but the Commission denied responsibility for the unequal administration of justice. ${ }^{49}$

The Dailey Commission handed its investigations over to special grand juries which used them as evidence in indictments. Chief Justice McDonald expressed the public mood as he charged one of these grand juries, arguing that

48. On the 1912 incident, see Jentz, "Labor, the Law, and Economics," 419-20. On the Chicago Crime Commission, see Tribune, Dec. 7, 1918, Jan. 5, 1919, Dec. 1, 10, and 11, 1920; Laurence Bergreen, Capone: the Man and the Era (New York: Simon \& Schuster, 1994), 86; Albert Lepawsky, The Judicial System of Metropolitan Chicago (Chicago: University of Chicago Press, 1932), 210-12, quotation on 210; Henry Barrett Chamberlin to Will Colvin, Dec. 22, 1923, Pardon Hearings. Also attending the December 1920 meeting were the Association of Commerce; the Cook County Bankers' Association; the Chicago Bar Association; and the Hamilton, Union League, and Iroquois Clubs - all elite business and professional societies.

49. Illinois, Senate, Report of Illinois Building Investigation Commission, 53rd General Assembly, 1923, 2, 4, 7-8, 100-01; Newell, Chicago and the Labor Movement, 80-81; Schneirov, Labor and Urban Politics, 313-14. 
many important unions in the city of Chicago are controlled by convicts and professional criminals, and that gunmen and convicts have seized hold of the offices of these unions for the sole purpose of ... [getting] money from the citizens of Chicago by a reign of terror, destroying law and order in this great community. ${ }^{50}$

In one sentence, McDonald expressed how the citizens' campaigns to fight crime moved from specific corrupt individuals - and there were corrupt union officials - to a generalized attack on labor unions as a threat to public order. The term reign of terror became common currency in newspaper reporting about labor affairs during the next two years.

Clearly there could be no compromise with such a challenge; and the effort to "clean up" the Chicago building industry, and particularly its unions, took on the air of a military campaign. This campaign reached full force just as the Flat Janitors took the lead in founding a new AFL affiliate, the Building Service Employees' International Union (BSEIU), in April 1921. In honor of its central role in the new international, the Flat Janitors became Local 1 in the new organization, although they kept their old name as well. On May 13, 1921, only three weeks after the chartering of the BSEIU, Quesse and nine other leaders of the Flat Janitors were indicted on a host of charges ranging from conspiracy to extort money to dynamiting buildings. They were part of the first set of indictments associated with the Dailey Commission hearings. By the fall, over 200 labor union officials, mainly from the building trades, were under indictment. 51

After the indictments Quesse sent an open letter to the members of his union in which he argued that the indictments were an effort "to break up our Union" led by the "Employers' Association" and its chief lawyer Dudley Taylor, who had led a successful test case against the union in 1914 that produced the Sullivan injunction. Quesse was right; Taylor and the Employers' Association were deeply involved in this new legal offensive against the Flat Janitors. Quesse's letter continued:

We know that the Employers have control of the Judges of the bench from time to time.... now is the opportune time for us to try to elect men to the Judicial Bench . . . whom I know, if elected, will insure us of a fair and impartial trial, not only at this time, but [in] all other cases.

He concluded with a call to resistance against the effort to break up the union: "It is our bread and butter, and we are not going to let them do it .... We are going to continue fighting like we know how, for your

50. Report of Illinois Building Investigation Commission, 45-46.

51. Jentz, "Citizenship, Self-Respect, and Political Power," 4, 20-21; Tribune, May 1, 13, and 14, 1921; Willard M. McEwen, testimony, official transcript, Pardon Hearings, 2-4. benefit as well as ours." Fighting "like we know how" meant voting for the eighteen judges he listed at the end of the letter. The eighteen composed a slate set up by Mayor Thompson to contest a special judicial election in June 1921. The special election was itself part of a contemporary battle against Thompson's huge patronage-fueled political faction. Although Thompson's slate lost to a bipartisan coalition endorsed by the Tribune, the Flat Janitors made friends among the losing candidates who would help them later. Quesse's political initiative in this judicial election illustrated the common pursuit of "negative" political goals by AFL unions, in which they engaged in politics to resist the use of the state against them. The employer's use of the courts led the Flat Janitors into an even stronger alliance with Mayor Thompson. ${ }^{52}$

The Flat Janitors' leaders had time to organize for this special judicial election because their trial was delayed for seven months after the indictments in May. The delay may have resulted from the conflict in the construction industry: the prosecution of the Flat Janitors was really part of this larger battle. In the fall of 1921 - while over 200 union leaders in the building trades were under indictment - construction unions and contractors agreed to an arbitration of their bitter differences. They chose Kenesaw Mountain Landis, famous for restoring the reputation of professional baseball after the 1919 White Sox scandals. Landis ruled in favor of the contractors on practically every issue, even imposing a lower scale of wages than they had anticipated paying. Employers organized the Citizens' Committee to Enforce the Landis Award - usually simply called the Landis Award - to insure that the construction unions complied with Landis's decision. It was by no means clear that they would, despite the mass of indictments. ${ }^{53}$

Among its many activities, the Landis Award hired Edwin J. Raber, an associate of Dudley Taylor's, to aid the state's attorney in the case against the Flat Janitors. Raber began work in November 1921, well before the union leaders' trial began in January. Although paid by a private organization of employers, Raber represented the state's attorney at the trial and in several of the subsequent proceedings against the

52. On Taylor's involvement in the case against the Flat Janitors, see Dudley Taylor to Len Small, Dec. 21, 1923, Pardon Hearings. Quesse quotations are from William F. Quesse to "Sir and Brother," [May 1921], Unprocessed SEIU Collection, Wayne State, SEIU Accession No. 1542, Box 85, Shipment Date, Sept. 1997. The judgeships at issue in this election appointed the commissioners for the city's huge park system on the South Side, and thus indirectly controlled the patronage there; Douglas Bukowski, "According to Image: William Hale Thompson and the Politics of Chicago, 1915-1931" (Ph.D. diss., University of Illinois at Chicago, 1989), 236-37. On the AFL and negative political goals, see Robin Archer, "Unions, Courts, and Parties: Judicial Repression and Labor Politics in Late Nineteenth-Century America," Politics and Society, 26 (1998): 402-5.

53. Schneirov and Suhrbur, Union Brotherhood, 101-2; William Haber, Industrial Relations in the Building Industry (Cambridge: Harvard University Press, 1930), 388-89. 
union, including hearings before the state's Board of Paroles and Pardons in 1924. Raber worked closely with Dudley Taylor, who claimed that the prosecution of the Flat Janitors "was based on an investigation" made by the Employers' Association, which hired him. This blending of private interest and public power in the administration of justice was standard practice, and even institutionalized in the Crime Commission, which often served as an "unofficial prosecuting authority." 54

The Flat Janitors' leaders simply assumed that employers powerfully influenced Chicago's judicial system; and, in fact, Quesse's open letter to the membership called on the union to do the same. The leaders suspected that the seven-month delay in their trial was part of the building owners' negotiating strategy: the owners were using their power over the state's attorney to time the trial so that it coincided with the annual contract negotiations, which always began in December and were usually resolved in January. Refusing to come to terms in December, the building owners, so the labor leaders thought, hoped to provoke the union into a strike while all of its top leaders were on trial. A leaderless union on strike, especially one composed of unskilled black and immigrant workers, could presumably be destroyed. When January and the trial arrived, Local 1's leaders refused to initiate a strike and won their case. The jury could not reach a verdict and was dismissed on February 4,1922 . Nine of the twelve jurors had voted for acquittal; and, out of ten counts in the indictment, "conspiracy to boycott" was the only one on which the jury came close to agreeing. ${ }^{55}$

Another victory for the Flat Janitors soon followed. Early in 1922, just as the trial of the leaders began, the Real Estate Board and the union submitted the annual contract to arbitration. The arbitrator agreed to by the union and the Board was Judge Bernard Barasa, a municipal court judge specializing in rent matters. He had been one of Quesse's eighteen judicial endorsements the previous June, garnering the most votes on the slate; and he almost certainly owed his current judgeship to the Thompson organization. The Real Estate Board had to be aware of Barasa's political connections when it agreed to him as arbitrator. Why the Board agreed to Barasa's appointment poses a conundrum, although it may have felt some of the pressure claimed by Oscar Nelson and Quesse. According to Nelson, vice president of the Chicago Federation of Labor, the union threatened to publish information about "certain members of the real estate board, their transactions, their manipulations,

54. On Raber, see Illinois Federation of Labor, Weekly News Letter (hereafter IFL News Letter), Apr. 19, 1924; Edwin Raber, testimony, official transcript, Pardon Hearings, 58. Taylor quote from Taylor to Small, Dec. 21, 1923. Quote on the Crime Commission from Lepawsky, Judicial System of Metropolitan Chicago, 211.

55. Oscar Nelson, testimony, official transcript, Pardon Hearings, $35-36$. painting contracts, plumbing contracts; and how they juggled the situation." Quesse said they pushed the Board to arbitration with "publicity." Nelson and Quesse likely overstated their influence. The Real Estate Board was not the same employers group most actively prosecuting the case against the Flat Janitors, and it was probably more concerned with getting a favorable contract than destroying the union. The Board's history of negotiating with the Flat Janitors over the past four years indicated that containing labor-management conflict within the cartel was acceptable to it. ${ }^{56}$

Judge Barasa's role as arbitrator publicly sanctioned the powerful positions of the Flat Janitors and the Real Estate Board in the cartel, just as Police Chief Fitzmorris's arbitration had done the year previously. Barasa went further than Fitzmorris, however, when he announced his decision on March 18, 1922. His ruling improved working conditions while preserving the current wage rates, including the "sliding scale" that had automatically increased the janitors' wages during the postwar inflation. More important, Barasa created a Permanent Arbitration Board consisting of one member appointed by the union, one by the Real Estate Board, and himself as chairman. He established the Arbitration Board for five years, after which the system would be reexamined. All labor disputes had to be submitted to it, and no strikes were allowed during its deliberations. Changes in wage rates would be considered every March 1, a concession to the Real Estate Board, which did not want strikes in the depth of winter when tenants were most vulnerable. ${ }^{57}$

Barasa's decision institutionalized the cartel with its three key players - the Flat Janitors, the Real Estate Board, and Thompson's political faction. It would be a mistake to see Barasa's decision as the state (through the courts) instituting a corporatist system, because the decisions of the Permanent Arbitration Board lacked the force of law and because the union actually enforced them, not the government. This arbitration mechanism presupposed the consent of the parties involved, as had all such proposals made by the Flat Janitors since their initial organizing campaign in 1902. The fact that neither the union nor the Real Estate Board challenged Barasa's decision in court indicated that they consented. The Flat Janitor's role in the cartel under the Permanent Arbitration Board was analogous to that of the United

56. Barasa's ethnic ties may also have inclined him to a labor union with an immigrant majority. Prominent in Chicago's large Italian community, Barasa had been knighted in Italy for his role in raising funds for the relief of Italian refugees during and after World War I. Barasa was born in Michigan of an Italian father and native-born mother; he married a native-born woman, both of whose parents were Italian-born; Chicago Herald and Examiner, May 17, 1919; U.S. federal manuscript census for 1910.

For the Nelson and Quesse quotes see Oscar Nelson, testimony, official transcript, Pardon Hearings, 35-36; [Quesse], "To the Public," 6.

57. Chicago Realtor, Apr. 1922, 38; [Quesse], "To the Public," 6. 
Mine Workers under the National Industrial Recovery Act (NIRA) in the first New Deal. The closest the United States has come to a corporatist system, the NIRA was declared unconstitutional within a few years of its birth. During its short life, agreements in the bituminous coal industry were actually enforced by the United Mine Workers Union, and thus the NIRA meant not corporatism, or even a cartel managed by the state, so much as union enforced collective bargaining, which profited from state sanctioning. Analogously, Barasa did not represent the state so much as Big Bill Thompson, whose political power was indispensable to the maintenance of the system. This quickly became clear as the legal attacks on the Flat Janitors intensified. ${ }^{58}$

Neither the trial nor Barasa's decision calmed the militant opponents of the Flat Janitors' Union. A period of public recrimination and hysteria followed the dismissal of the jury, heightened by the fact that the trials of the construction union leaders were not going much better for the prosecution than the case against the janitors. Led by the Tribune, the press went on the offensive. Quesse in particular felt the sting of the Tribune's rebuke. He concluded that,

\begin{abstract}
If you are a power of any kind politically and you don't cooperate with the Chicago Tribune, you are nailed and convicted before you start .... The Tribune and the other newspapers went after me so hard that everybody thought that this fellow Quesse had horns on him. ${ }^{59}$
\end{abstract}

The press also attacked the jury in the janitors' case. It accused one juror of taking bribes from Quesse, and both of them were indicted on March 25, 1922, for jury tampering; bail was set at $\$ 15,000$ each. That charge was subsequently dropped. A grand jury indictment was sought against Local 1's lawyer. The foreman of the jury in the first janitors' case, who had been employed by a bank for over twenty years, was fired under suspicious circumstances. Even judges began publicly calling on juries to reach convictions, while other judges criticized their colleagues for their behavior. By late March, the public mood had become so poisoned that the Church League for Industrial Democracy, a Protestant reform group, ran an advertisement in the Tribune saying that, "Daily and copiously the public is being fed with stories of 'the Crimes of Labor'," while employers departed for their vacations in exotic places. Granting that there was corruption in the labor movement, the Church

58. On the NIRA and the coal industry see Bowman, "When Workers Organize Capitalists," 318-19. The analysis in this paragraph profited from discussions with Richard Schneirov.

59. William F. Quesse, "Application for Pardon or Commutation of Sentence Filed for the January 1924 Term," January 8, 1924, Pardon Hearings. According to Oscar Nelson's testimony, there were 276 indictments of labor leaders in 1921, which resulted in 40 convictions, ten of which were of Local 1's leaders; official transcript, Pardon Hearings, 37.
League argued that, "At the same time the whole of Labor should not be condemned for the vicious acts of certain leaders."60

According to a prominent Illinois labor leader, the spring of 1922 was a time when "men of all classes lost their heads." 61 One reason was increasing violence, much of it associated with conflict in the construction industry over the Landis Award. On May 9, 1922, two policemen were gunned down in association with a bombing at an open-shop glazier's firm. Police arrested 163 construction union leaders, although only three were subsequently indicted. According to the magazine of the Association of Commerce, the killings "aroused the law abiding element in Chicago to a level of indignation unequaled since the Haymarket riots." 62 In this atmosphere, the second trial of the Flat Janitors' leaders began.

The hearing of evidence in the second trial began on May 31, 1922, after a six-week effort to select a impartial jury. The mood of both the press and the state's attorney was illustrated during the first two days of June when, just after the trial began, the Tribune reported that the state's attorney had appointed eleven new special assistants to "assist him in the work of suppressing labor terrorism in Chicago," while the next day it noted that six new judges in the Criminal Court would help "clean up" the 170 pending "labor 'terrorist" cases. Disregarding such hostile public opinion, Quesse had not fought a retrial, mistakenly thinking he and his fellow leaders would be vindicated. They were tried on the same charges as in the first trial and under the same judge, despite their request for a new one. They were all convicted on June 9 and sentenced on June 29 to from one to five years in the state penitentiary. According to the Tribune, the conviction as "the greatest victory thus far obtained by the state against labor terrorists." 63

The actual charges on which they had been convicted were subject to dispute, and this ambiguity became part of their appeals. The jury named one of the ten counts of the indictment specifically - Number 7 - but referred to others, unnamed. Judge Swanson concluded that they were convicted on the seventh count, the longest one, which included both conspiracy to boycott and conspiracy to extort money. They were thus acquitted on the nine other counts, which

60. The advertisement ran in the Mar. 29 Tribune and was reprinted in The New Majority, Apr. 8, 1922. On the legal developments during the spring see Criminal Court of Cook County, Case No. 28082, People of the State of Illinois v. William F. Quesse and Theodore Lodin, March 1922, Clerk of the Circuit Court of Cook County Archives, Chicago, IL; Joseph Harrington, testimony, official transcript, Pardon Hearings, 22.

61. Victor Olander, testimony, official transcript, Pardon Hearings, 90-92, quote on 92.

62. On the bombing incident and for the quotation from the Association of Commerce see Schneirov and Suhrbur, Union Brotherhood, 104.

63. Tribune, June 1, 2, and 10, 1922. On Quesse's thinking about the second trial, see The New Majority, Feb. 11, 1922. 
included, among other things, conspiracy to defraud building owners and to dynamite their buildings. In its ruling the Court of Appeals stressed only the conspiracy to boycott, finding that alleging extortion was "unnecessary," since conspiracy to boycott was itself a crime in Illinois. In its decision the Illinois Supreme Court did not refer to boycotting, stressing their conviction on conspiracy to extort money. Both courts denied Local 1's appeals, the decision of the supreme court coming in December 1923, a year and a half after the sentencing. Illinois courts had decided that Local 1's leaders were guilty of "conspiracy," and the strongest case was on "conspiracy to boycott." 64

Quesse had already begun organizing politically to reverse the original verdict. When the Illinois Supreme Court denied the appeal, this political mobilization moved into high gear, dwarfing the previous effort to elect judges two years previously. The Chicago and Illinois Federations of Labor helped the Flat Janitors organize a state-wide petition campaign for a pardon by the governor. Janitors throughout the city carried petitions through their buildings, provoking building owners to write the governor in an effort to disparage their significance: "Janitors in buildings operated by us have been circulating petitions misrepresenting facts in the case and a number of women in our buildings have signed these petitions with an absolute misunderstanding of what they are signing." The campaign collected 228,000 signatures throughout the state. The union also succeeded in having roughly sixty apartment building owners, all members of the Chicago Board of Real Estate, write the governor favoring a pardon. The leaders of the Real Estate Board countered with their own campaign against the pardon which, not surprisingly, produced more letters, about 300. Compared to labor's effort, however, the Board's campaign was modest and not commensurate with its financial and political resources. ${ }^{65}$

To support a pardon, Quesse helped organize the Cook County Wage Earners League, a sort of labor political action committee composed of a wide range of local union leaders. A power in local politics for the rest of the decade, the League used its influence to aid union organizing. The League actively supported Governor Len Small's 1924 campaign for reelection, and at the same time Quesse also made himself personally useful to Small, who thanked Quesse for "guarding my interests." ${ }^{\prime 66}$ Len Small needed help, in part because he had been indicted - but then ac-

64. Appellate Court of Illinois, First District, People of the State of Illinois $v$. William F. Quesse, et al., October Term, 1923, "Abstract of Record," Pardon Hearings, 16-17; Supreme Court of Illinois, Case No. 15558, People of the State of Illinois v. William F. Quesse, et al., December 19, 1923 (310 Ill. 467; 142 N.E. 187).

65. Quote from Albert W. Swayne to Len Small, Jan. 11, 1924, Pardon Hearings. The letters from both sides are in the Pardon Hearing Files.

66. Len Small to William F. Quesse, May 26, 1924, SEIU Microfilm Collection, Reel 1, Archives of Labor and Urban Affairs, Wayne State University (hereafter SEIU Microfilm, Wayne State). quitted - in 1921 for embezzlement and conspiracy during his earlier term as state treasurer. Suspicions remained, and Small had to pay a substantial settlement in a related civil suit. Quesse was not above flattery to get what he wanted from Small. In a speech at the initiation of the pardon proceeding in January 1924, Quesse said,

Whether the Governor does a favor for me or not, I think he has done enough for organized labor to ask every single labor man to give him their support. I think he is the greatest Governor we have ever had. ${ }^{67}$

In addition to flattery, Quesse used the influence that came through his years of cooperation with Big Bill Thompson. Thompson and Small were close allies, and to be reelected Small needed the active support of Thompson's numerous friends in Chicago. ${ }^{68}$

Chaired by Governor Small, the Board of Paroles and Pardons met in Springfield on April 11, 1924, to hear the case of the Flat Janitors' leaders. Quesse was joined by forty-five labor leaders from throughout the state. He also laid on the table the petitions with 228,000 signatures supporting a pardon. Opposing a pardon was Edwin Raber, representing the State's Attorney of Cook County, and indirectly, his employer, the Landis Award. Joining Raber was J. L. Vette, a vice president of the Chicago Real Estate Board. The preponderance of both institutional and voting power that Quesse had brought with him into the room helped determine the outcome in the Flat Janitors' favor. So did the testimony during a long day of hearings that began early and lasted well into the evening.

Delivering the first and most important testimony in favor of a pardon was Willard M. McEwen, the union's lawyer at the hearing and a former judge in the Cook County Superior Court. The fact that he had served eight years in the same court system that produced the conviction added to the weight of his testimony. Throughout his presentation, McEwen indicted the legitimacy of intervention in the Cook County judicial system by employers and the Chicago Crime Commission. In addition to technical points about the counts in the indictment, McEwen had two major arguments. First of all, he attacked the law of conspiracy in Illinois, arguing that it was easily exploited by employers as a weapon against labor - an

67. Quesse, "Application for Pardon."

68. On the Cook County Wage Earners League see Bukowsky, Big Bill Thompson, 185, 188; Cooper, "History of the BSEIU," 2829; Cook County Wage Earners League and Illinois State Federation of Labor, open letter, SEIU Microfilm, Wayne State, Reel 1, n.d.; William McFetridge, speech, "Proceedings, Building Service Employees International Union, May 1, 1928, Bismark Hotel, Chicago, Ill." (hereafter "BSEIU Proceedings 1928"), Unprocessed SEIU Collection, Wayne State, SEIU Accession No. 1542, Box 38, Shipment Date, Sept. 1997, 54-55. On Len Small, see Robert Sobel and John Raime, ed., Biographical Directory of the Governors of the United States, 1789-1978, 4 vols. (Westport, CT: Meckler Books, 1978), 1:384. On the alliance of Thompson and Small see Tribune, Dec. 10, 1920; Bukowsky, Big Bill Thompson, 111-12, 162-63. 
argument that had contemporary academic support. Originally passed in 1874, McEwen argued, the Illinois law was so vague that it could be interpreted to cover practically any labor initiative threatening employers. As used in the janitors' case, the law of conspiracy allowed for so many charges to be piled up that the jury concluded some crime must have been committed; thus it convicted on the vaguest charge, conspiracy to boycott, in order to cover the ground. Broad in scope and vague in content, the law of conspiracy was a tool, wrapped in public garb, easily available for the gain of private interests. McEwen had to indict the law of conspiracy because Quesse and his fellow leaders were in fact guilty of "conspiracy to boycott" every time they struck a building hiring nonunion labor. Boycotting services of all types was their main weapon. The Illinois labor movement considered such tactics legitimate, though the law did not. ${ }^{69}$

The conspiracy law was exploited in this way, continued McEwen, when employers used their power and wealth to gain access to the state's attorney's office. The state's attorney even used private lawyers, like Edwin Raber, to collect evidence and try cases. With the state's attorney and the grand jury behind them, these private interests

always ... appeared to be the ones who are standing upon law and order, always the publicity goes to the lawlessness of the working man. So it has built up a public [sentiment] that weighs heavily and which the working-man has had to combat.

Cooperative judges encouraged grand juries to broaden their investigations beyond their original intent as a way to prejudice public opinion in the city against labor. According to McEwen, the press did the same, the Tribune with unbridled enthusiasm. Such use of the criminal justice system as an "instrument" for private purposes was evident in the indictment of the building trades unionists after the Dailey Com-

69. McEwen served as a judge in the Cook County Superior Court from 1902 to 1910; Who's Who in Chicago 1926. For his testimony, see Willard M. McEwen, testimony, official transcript, Pardon Hearings, 1-10.

For legal scholarship supporting McEwen see Francis B. Sayre, "Criminal Conspiracy," Harvard Law Review 35 (1921-22): 393427. McEwen's phrasing of his argument even echoed Sayre; see, 393-94. The labor movement's cynicism about the law of conspiracy was heightened by the fact that it criminalized labor activities but not employer blacklists of union workingmen, which were also boycotts.

On the legitimacy of boycotting see the petition supporting a pardon circulated by the Illinois Federation of Labor; "To His Excellency, Honorable Len Small, Governor of the State of Illinois," Pardon Hearings.

On the problematical legal status of labor unions in this era see Earl R. Beckner, A History of Labor Legislation in Illinois (Chicago: University of Chicago Press, 1929) 8, 59; Christopher L. Tomlins, The State and the Unions: Labor Relations, Law, and the Organized Labor Movement in America, 1880-1960 (Cambridge: Cambridge University Press, 1985), 33; William E. Forbath, Law and the Shaping of the American Labor Movement (Cambridge, MA: Harvard University Press, 1991), 60-63, 76-77, 82-83, 88-89. mission hearings in 1921. Once, said McEwen, it became clear that the building trades unions would abide by the Landis Award the state's attorney simply "struck off," or withdrew, the indictments of over 200 of their leaders. The trials of the janitors were part of the same misuse of public authority to intimidate the labor movement. Thus, said McEwen, the convictions of Local 1's leaders had lost any public character, remaining only as the gains of private interest. They should therefore be overturned. In this bravura performance, McEwen utilized a prevailing concept of separating public power and private interest that had helped reformers in the Progressive Era attack political machines - concepts that also made it difficult to legitimate the state's involvement in managing cartels, much less setting up corporatist systems. ${ }^{70}$

Compared to McEwen, the two opponents of a pardon were by no means as coherent or effective, mainly because they represented different business interests with different agendas and distinct attitudes toward labor. Edwin J. Raber again represented the state's attorney and the Landis Award, as he had at the trial. His testimony repeated the charges and summarized the evidence presented at the trial, most of which had not been accepted by the jury. He stressed the familiar themes of conspiracy and labor terrorism. There was a pro forma quality to Raber's presentation, probably indicating that the Landis Award had written off the whole affair after achieving its larger goals of pressuring the building trades unions into accepting Judge Landis's arbitration decision. The fact that the state's attorney himself did not even bother to attend reinforces this interpretation. For whatever reasons, and despite its open-shop predilections, the business coalition hiring Raber did not expend the considerable resources that would have been necessary to defeat the well-organized union campaign for a pardon. ${ }^{71}$

In his testimony, C. L. Vette, a vice president of the Chicago Real Estate Board, deflated Raber's presentation by his faint support for it. Vette also revealed divisions within the Real Estate Board about dealing with the Flat Janitors. In January, the officers of the Board had called on members to write the governor opposing a pardon, and a membership meeting shortly afterward passed a resolution against a pardon as well. Yet, by the pardon hearings in April, there were letters from Board members both sup-

70. McEwen, testimony, official transcript, Pardon Hearings, 1-10; quotations on 4.

71. On Raber and Taylor see testimonies of Oscar Nelson, John A. Walker, and Edwin J. Raber, official transcript, Pardon Hearings, 32, 71; Jentz, "Labor, the Law, and Economics," 422-23; on Raber's association with Taylor see Taylor to Small, Dec. 21, 1923.

A construction boom in the housing industry may have contributed to the decline of interest in prosecuting the janitors. A shortage of housing immediately after World War I sparked the Dailey Commission's investigation of the construction unions, while the passing of the shortage lessened public support for "cleaning up" the construction industry. On the construction boom see Chicago Real Estate, June 1922, 23. 
porting and opposing a pardon; and the organization only managed to send a vice president to state its case at the hearings in the presence of forty-five labor leaders from throughout the state. Vette testified that, "While it is true the Real Estate Board had no part whatever in this persecution [word used in the transcript] so far as I know they were not interested in it as a Board." He said this even though the Board of Pardons and Paroles had a copy of the January resolution against a pardon, as well as letters from officers of the Real Estate Board taking the same position. Vette went on to say,

\begin{abstract}
Now whether or not they [the Flat Janitors] committed these outrages, you gentlemen know just as much about it as I do. The information I have on that subject comes from hearing Mr. Raber tell his story. I have no reason to doubt it.
\end{abstract}

This was simply disingenuous. As the Real Estate Board's attorney for ten years previously, Vette must have heard the numerous complaints from Board members about the Flat Janitors' tactics, including sabotage against buildings during strikes. Vette's testimony revealed a Board divided about the Flat Janitors' Union and unwilling or unable to mobilize its enormous resources to put the union's leaders in jail. Enough of the Board's leadership was satisfied with the cartel - formalized two years earlier by Judge Barasa - to keep the Board from disrupting the system by decapitating Flat Janitors' Union, a task that would have been politically expensive as well. ${ }^{72}$

Conflicting attitudes among the Board's members reinforced the leaders' ambivalence. The fact that the Real Estate Board only produced about 300 letters against a pardon, when the organization had over 5,800 members, illustrated that the members were not united in righteous rage against the Flat Janitors. This is not to say that they liked the union either. Some of the Board's members held the union responsible for creating attitudes among janitors inappropriate for people of their class, an affront heightened by the janitors' being overwhelmingly immigrants and African Americans. One owner wrote, "The janitors of our buildings were not amenable to reason during the Quesse regime ... they virtually assumed the role of dictators." These dictatorial attitudes usually involved a janitor's refusal to do work, such as nailing loose boards, that the labor contract reserved for other trade unions. Another owner was fined by Quesse for paying an African American jan-

72. On the Real Estate Board's actions in early 1924 against a pardon, see the following records of the Pardon Hearings: Louis T. Jamme to members of the Chicago Board of Real Estate, Jan. 10, 1924; Henry G. Zander, Orville P. Curran, Jr., and J. L. Hess to Illinois Board of Paroles and Pardons, Feb. 8, 1924; N. E. Christianson to Len Small, Feb. 4, 1924.

On Vette's testimony see official transcript, Pardon Hearings, 60-61. On Vette's service as attorney for the Real Estate Board see Chicago Realtor and Chicago Real Estate, Dec. 1921, 10. itor below the union scale. Quesse "pre-emptorily $[s i c]$ assessed a fine against me" and, even worse, behaved rudely: "I was never so abused or mistreated in my life and in the most profane way." Such class perceptions reinforced these owners' anger against the changes brought by the union, including higher wages and precisely defined work tasks. Other members of the Real Estate Board saw compensating benefits to the union. ${ }^{73}$

About sixty letters from Real Estate Board members favored a pardon. Some of them followed a standard format proposed by the union, naturally exonerating the leaders of the numerous charges against them. These letters, all directed to Governor Small, also noted that the union's members "have been strong supporters of yours and William Hale Thompson," a political point reinforced by the petitions favoring a pardon signed by almost a quarter of a million voters. The more original letters illustrated why the Real Estate Board was divided about the union. One owner wrote that the union's opponents simply "did not feel disposed to pay the scale" of union wages: "I am on the side representing capital, but I believe in being fair to everyone . . . many Chicago property owners are glad to receive the increased rentals, but would like to keep the janitor's wage as low as possible." Being "fair" was feasible for such owners if the universal enforcement of the union contract protected them from non-union competition. The Flat Janitors' Union was strong enough in the metropolitan labor market to provide such universal enforcement, at least if its top ten leaders were not in jail. At the pardon hearings, Oscar Nelson, vice president of the Chicago Federation of Labor, stated the point more generally, arguing that "the average investor in real estate" realized that the Flat Janitors' Union "has stabilized the real estate market." The Board had addressed this constituency when it reported on Barasa's ruling in March 1922, emphasizing the judge's commitment to providing "'steady uninterrupted service"” by competent janitors. Enough members appreciated such stability to make the Real Estate Board ambivalent about sending the union's leaders to the state penitentiary. ${ }^{74}$

On April 12, 1924, Governor Len Small pardoned Quesse and the other leaders - four days after he had won a hotly contested primary election for the Republican nomination for governor. The candidate opposing him had been heavily supported by the

73. In 1921 the Board had 5,800 members, and it probably had more by the spring of 1924 , since it was undertaking a membership drive; Chicago Real Estate, March 1921, 18. For quotations see Cornelius Teninga to Governor Len Small, Jan. 11, 1924, Pardon Hearings; Glenwood Preble to Governor Len Small, Jan. 11, 1924, Pardon Hearings.

74. "Fair" quote from B. M. Carra to Governor Len Small, Dec. 31, 1923, Pardon Hearings; Oscar Nelson, testimony, official transcript, Pardon Hearings, 35; Barasa as cited in Chicago Realtor, April 1922,38 . On the regulatory function of unions in certain markets see Gordon, New Deals, 87. 
Tribune, which accused Small of multiple charges of corruption. Both the Illinois Federation of Labor and the Flat Janitors had heavily supported Small, and they continued to do so through Small's victory in the November elections. ${ }^{75}$

The legal assault on the union in the 1920 s pushed it to mobilize political resources that it had cultivated earlier during World War I. In the process, it became even more important as a political interest group in Chicago's power centers, building networks of influence that sustained not only itself but also the larger Chicago labor movement as well as William Hale Thompson's political faction. The men involved in these networks participated in Quesse's funeral in February 1927. Officially he died of cancer, but the oral tradition of the union attributes his death to injuries suffered in battles with the police and private guards in the early days of organizing. Quesse remained active almost to the end, writing letters of support to candidates for local office several days before he died. He also anointed his successor in a "letter from beyond the grave" read to a mass membership meeting soon after his death. William Hale Thompson addressed the same mournful assembly. ${ }^{76}$

Leaders of the Chicago labor movement stood out prominently at Quesse's mammoth funeral service, as did five Roman Catholic priests and a crowd of public officials. Participating as honorary pallbearers were Governor Len Small, a United States Senator from Illinois, 8 Illinois State Senators, 22 Illinois State Assemblymen, 14 Chicago Aldermen, and 31 judges one of whom was Bernard Barasa. Also participating was Anton Cermak, who would defeat Thompson in the mayoralty election of 1931 and go on to found the famous Chicago Democratic machine. Quesse told the Board of Pardons and Paroles that, "I never knew anything in my life but fight for what you want"; in Chicago during the $1920 \mathrm{~s}$, this meant turning his huge union local into a powerful political interest group with wide influence in the city and state. ${ }^{77}$

75. For labor support of Small in 1924 see the previously cited undated open letter from the Cook County Wage Earners League and the Illinois Federation of Labor, SEIU Wayne State, microfilm box 1; IFL News Letter, Apr. 5, 1924; Illinois State Federation of Labor, Proceedings. Forty-second Annual Convention. September 8-13, 1924 (Chicago: William C. Faehse, 1924), 212, 338-39.

The Flat Janitors worked through the Cook County Wage Earners League, which went on to fight other battles, resisting, for example, the frequent use of injunctions in labor conflicts, including one against female garment workers issued by Dennis E. Sullivan, the same judge who had ruled against the Flat Janitors in 1915 The League also used its political influence to aid the organization of both male and female workers in public institutions, including schools and hospitals. On the garment workers, see Chicago Herald and Examiner, Apr. 12, 1924; IFL News Letter, June 19, 1926. On hospital and school workers, see William McFetridge and Elizabeth A Grady, speeches, "BSEIU Proceedings 1928," 54-55, 78-79; BSEIU, "Cause and Effect of Organized Labor."

76. Ken Kinsch, retired officer of Local 1, discussed the causes of Quesse's death with the author; Cooper, "History of the BSEIU," 41; Federation News (Chicago), Feb. 26, 1927.

77. Quesse, "Application for Pardon," Pardon Hearings.

\section{THE FLAT JANITORS IN LABOR AND URBAN HISTORY}

The history of the Flat Janitors' Union contributes to the current reevaluation of the AFL, particularly by adding to knowledge of local unions rather than concentrating on the national organization and its policies. AFL unions have typically been seen as exclusive, racially segregated, male craft organizations pursuing narrow economic goals and conservative politics. Recently, such labor historians as Dorothy Sue Cobble and Richard Schneirov have criticized and expanded this view by analyzing a wider range of AFL unions and by reinterpreting the local labor movements in which they participated. Cobble applied her definition of occupational unionism to waitresses' unions' efforts to organize unskilled and semiskilled women working in scattered small firms. Providing a counterpart to the waitresses among unskilled male workers, the Flat Janitors' Union broadens the import of Cobble's analysis. The examples of both these AFL unions in the first third of the twentieth century argues for a reexamination of the federal unions through which the AFL tried to organize the unskilled work force. Since federal unions were inside the AFL but outside any particular national craft union, they more precisely met the organizational needs of the unskilled. The Flat Janitors were AFL Federal Union 14332 before becoming Local 1 of the new BSEIU. 78

Richard Schneirov's conception of a "new unionism" that emerged in Chicago by the 1890s places the discussion of AFL locals of unskilled workers in a wider context. The Knights of Labor's effort to organize both the skilled and unskilled provided a goal for the Chicago labor movement after the Knights' decline. In Chicago, AFL craft unions, particularly those in construction, tried various techniques for appealing to the unskilled, including advocating popular issues such as the minimum wage and shorter hours and promoting separate locals for workers such as hod carriers. These locals were then linked to other unions through participation in umbrella organizations such as the Building Trades Council. At the same time, this new unionism sought to build stronger locals by raising dues, increasing benefits, and employing full-time staff - measures that have defined business unionism but which did not necessarily imply the conservatism usually associated with the term. The people manning the new institutional apparatus of the unions had been through the upheavals of the 1880s and wanted stability while keep-

78. Cobble, Dishing It Out, 137-48. On federal unions see Lewis L. Lorwin, The American Federation of Labor: History, Policies, and Prospects (1933; Clifton, NJ: Augustus M. Kelley Publishers, 1972), 70-71; entry on "Federal Labor Unions" in American Federation of Labor, American Federation of Labor: History, Encyclopedia Reference Book (Washington, D.C.: American Federation of Labor, 1919), 230; Dorothy Sue Cobble, "Reviving the Federation's Historic Role in Organizing," (Working Paper; Washington DC: Institute for the Study of Labor Organization, 1996). 
ing alive some of their earlier goals. The efforts to organize unskilled workers in the 1890s attested to that. Finally, the new unionism tried to advance working-class interests by controlling markets for labor and sometimes for products, an effort that sometimes required cooperation with employers. Union label campaigns, for example, rewarded employers for union contracts by providing a reliable market for their products. The union label could also be used to protect the Chicago market from outside competition. ${ }^{79}$

The Flat Janitors' Union illustrated how several features of Schneirov's new unionism extended into the 1920s, most obviously the union's effort to control the labor market and willingness to cooperate with employers to do so. The Flat Janitors also profited from the efforts of other Chicago locals to organize unskilled workers. The union simply could not have been organized without the cooperation of the teamsters in particular, but also the building trades, all of whom honored the janitors' pickets of particular buildings they were striking. The janitors probably even derived from the building trades the idea of numberous trades striking one employer, instead of one trade striking across its own industry. The practice orginated from two decisive strikes in 1891 in which stronger building trades unions with labor agreements supported those without. ${ }^{80}$ As noted earlier, the janitors also took their model of arbitration from the building trades. The Flat Janitors' Union was an integral part of a Chicago labor movement trying to organize a wide range of skilled and unskilled workers under the aegis of the AFL.

The history of the Flat Janitors' Union can also contribute to reinterpreting the AFL's policy of voluntarism. Voluntarism presupposed that the AFL would not form its own labor party; rather, it would advance its political interests through friendly forces in both major parties, while pursuing its economic goals through organization at the workplace. Voluntarism allowed the organization to tilt toward the Democratic party during the Progressive Era, particularly in an effort to counteract the use of court injunctions against its unions.

Quesse practiced American Federation of Labor politics in the streets, and even in the basements where the janitors worked, using the full range of political tactics from grass roots organizing to deals with powerful contending organizations. In Quesse's hands, voluntarism meant partisan politics of a distinctive kind aimed mainly, though not exclusively, at achieving the traditional AFL goal of getting the state out of the way. In other words, the Flat Janitors pursued mainstream AFL goals with political means analogous to those used by national labor organizations beginning in the New Deal, tactics which made them,

79. Schneirov, Labor and Urban Politics, 307-16. 80. Ibid., 309. in J. David Greenstone's terms, into a "Democratic party campaign organization." 81 The Flat Janitors, of course, practically became a campaign organization of a Republican faction in Chicago. Such an expanded view of labor union politics in this era can open up new dimensions of urban political systems, especially when linked to the concept of metropolitan unionism.

Barbara Newell, Richard Schneirov, and Colin Gordon have all addressed this concept. Gordon defines it as "a form of collective bargaining that groups workers by region and occupation rather than by work site and industry," which he finds most prominently in local markets of northern and western cities from the Progressive Era through World War II. There, metropolitan unionism concentrated in some skilled trades, particularly construction; in unskilled service occupations such as delivery drivers, janitors, and elivators operators; and, in local manufacturing, most famously in the needle trades. Politically, some metropolitan unions actually forged "a distinct identity and agenda in local politics," as well as supported each other in organizing drives and occasionaly jointly supplied services such health care. The concept of a political cartel employed here helps analyze the politics of such metropolitan unions. The Flat Janitors needed political power to achieve their collective bargaining goals, most obviously because the arbitration mechanism they always preferred frequently broke down; and it took Big Bill Thomspon to fix it. This function of political power for the Flat Janitors took the politics of their metropolitan unionism beyond the AFL's negative goal of keeping the state at bay and placed it at the center of the institution's life. Politics for the Flat Janitors was a policy instrument as well as a shield against the state. Perhaps the Flat Janitors were unique in this regard, but the politics of other metropolitan unions could be fruitfully addressed with the Flat Janitors and their political cartel in mind. ${ }^{82}$

Similarly, the example of the Flat Janitors could aid in rethinking the political economy of urban machines. Students of labor and political machines have been most interested in how bosses and their minions in the wards influenced the politics of the labor movement. Typically, and accurately, labor historians have seen the machines coopting labor leaders and mitigating the radicalism of labor's political demands. A secondary concern has been the role of political machines in assimilating the workers as immigrants into American industrial society through participation in the major parties. In other words, most scholarship on labor and machines has emphasized the political

81. J. David Greenstone, Labor in American Politics (New York: Alfred A. Knopf, 1969), 6.

82. Gordon, "Lost City of Solidarity," 562-66, quote on 562; Newell, Chicago and the Labor Movement, 209-11, 225; Schneirov, Labor and Urban Politics, 314-16. 
side of political economy. The history of the Flat Janitors, as well as the concepts of metropolitan unionism and political cartels, help reveal the economic role of the machines in metropolitan economies and thus the roots of their power beyond the ballot box. ${ }^{83}$

From this perspective, one can see urban machines addressing one of the central problems of the early twentieth century - the control of markets in a democratic polity. The progressive movement is most famous for its creative initiatives on this issue, but the bosses and their allies came at it from their own angle, and, in a sense, from the bottom up. Their local or metropolitan efforts at market management can be compared to the progressives' endeavors aimed at the same goal on the state and national levels. And, finally, a political economy that contextualized and historicized machines within a metropolitan environment would help address Katznelson's concern with the "partial truth" of treating the state as an independent variable to explain working-class formation and labor politics. Labor and capital would both appear as shaping the capabilities and limits of machines and city governments, even as machines and the local state did the same for business and labor. ${ }^{84}$

Finally, Katznelson used one the most creative students of labor and politics, J. David Greenstone, to raise the issue of liberalism in America as a "boundary condition" setting paramaters around the coun-

83. On labor and machines, see Bridges, "Becoming American," and Shefter, "Trade Unions and Political Machines." For urban historians, the relationship of organized labor to machines is a secondary problem compared to their relationsips to immigrants, business, and their opponents, the municipal reformers. For a current summary of scholarly opinion see Howard P. Chudacoff and Judith E. Smith, The Evolution of American Urban Society, 5th ed. (Upper Saddle River, NJ: Prentice Hall, 2000), 157-82.

84. On labor, liberalism, and market regulation, see Schneirov, Labor and Urban Politics, 368-70; Katznelson's quote is from "Working-Class Formation and American Exceptionalism, Yet Again", 53. try's political life, even as its own character was at stake in periods of great crisis, such as the Civil War, the Progressive Era, and the New Deal. ${ }^{85}$ It may seem presumptuous to consider the history of the Flat Janitors in the presence of such historical dramas, but it's worth considering nonetheless for the light it might shed on the import of local politics in America. The Flat Janitors were a huge multi-racial, interethnic union of unskilled workers. Their sheer institutional presence combined with the articulation of their interests pushed against the prevailing "grammar of rules" defining legal union practice and, more generally, the exercise of collective power. The class dimension of these conflicts was articulated by the petition favoring a pardon for Quesse and the nine other leaders circulated throughout the state by the Illinois Federation of Labor. It argued that organizing tactics ruled illegal by the courts were considered legitimate by workers: "Labor Organizations that have built up and dignified Labor in all civilized countries are concerned over acts deemed innocent and justifiable by the great mass of laborers, but the right to do which is denied." ${ }^{86}$ In the broadest sense, the character of American liberalism was at stake in conflicts like these, at least liberalism as defined by the Illinois Legislature and the Circuit Courts of Cook County. Was it wide enough to accept union boycotts of buildings not hiring union janitors? The courts said no; and the labor movement, in alliance with Big Bill Thompson, said yes. This was an ongoing, ferocious battle taking place in local and state politics between the great periods of national crisis when the character of American liberalism shifted in decisive ways. Such local conflicts helped define the terms in which the larger battles were fought.

85. Ibid., 42.

86. "To His Excellency, Honorable Len Small, Governor of the State of Illinois," Pardon Hearings. 